\title{
Heterogeneous ice nucleation on dust particles sourced from nine deserts worldwide - Part 2: Deposition nucleation and condensation freezing
}

\author{
Yvonne Boose $^{1, \mathrm{a}}$, Philipp Baloh ${ }^{2}$, Michael Plötze ${ }^{3}$, Johannes Ofner ${ }^{4}$, Hinrich Grothe ${ }^{2}$, Berko Sierau ${ }^{1}$, \\ Ulrike Lohmann $^{1}$, and Zamin A. Kanji ${ }^{1}$ \\ ${ }^{1}$ Institute for Atmospheric and Climate Science, ETH Zürich, Zürich, Switzerland \\ ${ }^{2}$ Institute for Materials Chemistry, TU Wien, Vienna, Austria \\ ${ }^{3}$ Institute for Geotechnical Engineering, ETH Zürich, Zürich, Switzerland \\ ${ }^{4}$ Institute for Chemical Technologies and Analytics, TU Wien, Vienna, Austria \\ a now at: Institute of Atmospheric Physics, German Aerospace Center, Wessling, Germany
}

Correspondence: Yvonne Boose (yvonne.boose@ alumni.ethz.ch) and Zamin A. Kanji (zamin.kanji@env.ethz.ch)

Received: 29 September 2018 - Discussion started: 16 October 2018

Revised: 22 December 2018 - Accepted: 11 January 2019 - Published: 28 January 2019

\begin{abstract}
Mineral dust particles from deserts are amongst the most common ice nucleating particles in the atmosphere. The mineralogy of desert dust differs depending on the source region and can further fractionate during the dust emission processes. Mineralogy to a large extent explains the ice nucleation behavior of desert aerosol, but not entirely. Apart from pure mineral dust, desert aerosol particles often exhibit a coating or are mixed with small amounts of biological material. Aging on the ground or during atmospheric transport can deactivate nucleation sites, thus strong ice nucleating minerals may not exhibit their full potential. In the partner paper of this work, it was shown that mineralogy determines most but not all of the ice nucleation behavior in the immersion mode found for desert dust. In this study, the influence of semi-volatile organic compounds and the presence of crystal water on the ice nucleation behavior of desert aerosol is investigated. This work focuses on the deposition and condensation ice nucleation modes at temperatures between 238 and $242 \mathrm{~K}$ of 18 dust samples sourced from nine deserts worldwide. Chemical imaging of the particles' surface is used to determine the cause of the observed differences in ice nucleation. It is found that, while the ice nucleation ability of the majority of the dust samples is dominated by their quartz and feldspar content, in one carbonaceous sample it is mostly caused by organic matter, potentially cellulose and/or proteins. In contrast, the ice nucleation ability of an airborne Saharan sample is found to be dimin-
\end{abstract}

ished, likely by semi-volatile species covering ice nucleation active sites of the minerals. This study shows that in addition to mineralogy, other factors such as organics and crystal water content can alter the ice nucleation behavior of desert aerosol during atmospheric transport in various ways.

\section{Introduction}

The ice phase in clouds causes one of the largest uncertainties for understanding the role of clouds in the present climate and for projecting future climate (Boucher et al., 2013). While it is known that for the initial formation of ice in clouds warmer than $235 \mathrm{~K}$ certain aerosol particles, socalled ice nucleating particles (INPs), are necessary, many aspects of heterogeneous ice nucleation remain poorly understood (Coluzza et al., 2017; Kanji et al., 2017). Mineral dust is thought to be the most prevalent INP type in the atmosphere (Hande et al., 2015). Schaefer (1949) found naturally occurring mineral dust particles to nucleate ice at temperatures $T<258 \mathrm{~K}$. Cozic et al. (2008) and Kamphus et al. (2010) detected mineral dust in ice crystal residuals in mixed-phase clouds. In these clouds the most common ice nucleating mechanisms are likely immersion and contact freezing. Both mechanisms require a cloud droplet to form first and an INP to either initiate freezing from the inside of 
the droplet (immersion) or via contact with the surface of the droplet (contact freezing). Cziczo et al. (2013) observed mineral dust also in ice crystal residuals in cirrus clouds. When the relative humidity ( $\mathrm{RH})$ with respect to ice is high enough (e.g., $\mathrm{RH}_{\mathrm{i}}>140 \%$ at $238 \mathrm{~K}$ ), ice forms via homogeneous freezing of solution droplets without the help of an INP (Koop et al., 2000). At lower RH ice may form via immersion freezing on INPs in solution droplets (Zuberi et al., 2002) or via the deposition mode, where ice nucleation occurs on an INP directly from the vapor phase (Vali, 1985; Vali et al., 2015). Condensation freezing is understood as freezing occurring during the formation of a liquid phase, when water saturation is exceeded but before a droplet has formed. Recently, the differentiation between condensation and immersion freezing has been questioned (Marcolli, 2014; Vali et al., 2015). Furthermore, it has been suggested that freezing at water subsaturated $\left(\mathrm{RH}_{\mathrm{w}}<100 \%\right)$ conditions, referred to as deposition nucleation, may in some cases be explained by condensation and subsequent freezing of water in pores on the particles' surface (pore condensation and freezing - PCF; Marcolli, 2017).

Mineral dust is thought to have an influence on cloud microphysical processes on a global scale, with global dust emission rate estimates of up to $5 \mathrm{Pg} \mathrm{yr}^{-1}$ (Engelstaedter et al., 2006, and references therein). DeMott et al. (2003) found increased concentrations of INPs in air masses over Florida which carried Saharan dust, while Creamean et al. (2013) observed precipitation in California to be influenced by dust from Asia and the Sahara. Over Europe, Chou et al. (2011) and Boose et al. (2016a) found periods of Saharan dust advection to coincide with increased INP concentrations under mixed-phase cloud conditions. Even at the South Pole, Kumai (1976) identified about $60 \%$ of ice crystal residuals to be clay minerals.

For several decades, clay minerals were believed to be responsible for the ice activity of mineral dust, mainly due to their high mass fraction in airborne dust. Recently, Kfeldspars have been identified to nucleate ice at warmer temperatures or lower relative humidity than all other minerals, both in the immersion mode (Atkinson et al., 2013; Zolles et al., 2015) as well as in the deposition and condensation modes (Yakobi-Hancock et al., 2013). Paramonov et al. (2018) found the K-feldspar content to correlate well with the ice nucleation activity of dust at temperatures between 238 and $243 \mathrm{~K}$ for three dust samples from Iceland, China, and the Himalayas. While Kaufmann et al. (2016) found K-feldspar in only one out of eight dust samples collected in potential atmospheric dust source regions in South America, Asia, and Africa, we observed K-feldspar to be present in all but one sample from a collection of 21 samples from deserts around the world (Boose et al., 2016c). Furthermore, feldspars are prone to chemical weathering processes in acids or water which may passivate certain active sites and decrease the feldspar's ice nucleation activity (AugustinBauditz et al., 2014; Wex et al., 2014; Harrison et al., 2016).
The nature of these active sites is still under debate. It is suspected that they are associated with high energy defects in the lattice structure such as steps, cracks, and impurities (Fletcher, 1969; Marcolli et al., 2007) or crystal boundaries in twinned crystals (Harrison et al., 2016) where a (100) crystal plane is exposed to water or vapor (Kiselev et al., 2017). Whale et al. (2017) found that feldspars with perthitic microtexture, i.e., intergrowth of sodic alkali feldspar into a host of K-feldspar, have the highest ice nucleating ability. Berner and Holdren (1977) observed weathering to occur primarily at excess energy sites on the feldspar surface. During atmospheric transport, such chemical weathering processes or aging could alter the ice nucleation activity of feldspar particles compared to those on the ground or freshly cleaved crystals used in laboratory studies (Atkinson et al., 2013; Yakobi-Hancock et al., 2013; Harrison et al., 2016; Kiselev et al., 2017). By implementing parameterizations for marine organics and feldspar INPs into their global model, VergaraTemprado et al. (2017) found indications that terrestrial INP concentrations could be dominated by feldspar. However, atmospheric aging effects were not taken into account. Thus, feldspar has the potential to be the most important ice nucleating mineral in the atmosphere, but its atmospheric relevance is yet to be confirmed.

Atmospheric aging processes are challenging to observe in situ, thus several laboratory studies have mimicked potential aging processes. These processes often modify the surface of dust particles and, as such, the ice nucleation ability of mineral dust. Zolles et al. (2015) could block and unblock surface ice nucleation sites with selected organic molecules. Sulfuric acid coating leads to a reduction in the ice nucleation ability of mineral dust (Sullivan et al., 2010; Augustin-Bauditz et al., 2014), the exposure to low amounts of ozone increases it (Kanji et al., 2013), and coatings of organic aerosol make no difference to it in condensation mode (Koehler et al., 2010; Kanji et al., 2018). The presence of ammonium sulfate has been suggested to improve the ice nucleation ability of Saharan dust advected to Tenerife (Boose et al., 2016b). Recently, Kumar et al. (2018a) and Whale et al. (2018) confirmed that very dilute ammonium salt solutions $\left(<1 \mathrm{~mol} \mathrm{~kg}^{-1}\right)$ increase the ice nucleation temperature of microcline by 3 to $4.5 \mathrm{~K}$. While surface-collected dust particles from the Sahara were found to have negligible amounts of nitrate or sulfate, a high degree of mixing of nitrate and/or sulfate with mineral dust was observed after advection to Cape Verde, Tenerife, or Ireland (Kandler et al., 2007; Dall'Osto et al., 2010).

Residues from ice nucleating biological material such as fungal proteins or nanoscale pollenaceous INPs have been observed to adsorb to mineral dust while retaining their ice nucleation ability (Schnell, 1977; Conen et al., 2011; Augustin-Bauditz et al., 2016; O'Sullivan et al., 2015, 2016). Even though desert soils contain typically $<1 \%$ organic matter due to the low average annual precipitation (Troeh and Thompson, 2005), long-range transport of dust has been suggested to efficiently disperse bacteria on a global 
scale (Hara and Zhang, 2012). Enriched fluorescent particle concentrations, an indication for enriched biological material, were found in long-range transported Saharan dust by Kupiszewski et al. (2015) in ice crystal residuals from mixedphase clouds in the Swiss Alps and in condensation-mode INPs at $241 \mathrm{~K}$ by Boose et al. (2016b) on the Canary Islands. In contrast to biological material, secondary organic aerosol coatings have been observed to decrease the ice nucleation ability of dust particles in the laboratory in deposition mode (Möhler et al., 2008) but not in condensation mode (Koehler et al., 2010; Kanji et al., 2018).

In a partner paper to this work (Boose et al., 2016c) we investigated the immersion-mode ice nucleation activity of airborne dust samples, which were collected after atmospheric transport or sampled from the surface in deserts. We showed that the K-feldspar fraction, i.e., the fraction of microcline plus orthoclase, of these dust samples correlates well with the ice-active surface site density in the immersion mode at $T=253 \mathrm{~K}$. At $T \leq 245 \mathrm{~K}$ the best correlation of the ice nucleation activity was found for the bulk quartz plus feldspar (microcline, orthoclase, and plagioclase) content in the dust samples, while the fraction of clays was negatively correlated with the ice nucleation activity. Quartz alone has been found to show various immersion-mode ice nucleation activities in laboratory studies. Zolles et al. (2015) found quartz being active at temperatures comparable to microcline, while Atkinson et al. (2013) measured ice nucleation activity below feldspar temperatures but above those of clay. Kaufmann et al. (2016), in contrast, only observed ice nucleation activity at temperatures comparable to or lower than those of clays. These differences in ice nucleation ability can be related to the history of the quartz samples and different ways of pre-processing them (Zolles et al., 2015). Milling quartz samples leads to a breakup of $\mathrm{Si}-\mathrm{O}-\mathrm{Si}$ bridges on the surface, leading to the formation of $\mathrm{Si}-\mathrm{OH}$ and $\mathrm{Si}-\mathrm{O}-\mathrm{OH}$ in the presence of water vapor, which increases the ice nucleation activity of the quartz particles (Kumar et al., 2018b). Quartz is the most abundant mineral on Earth and is widely spread in various soils. It is highly resistant to chemical and mechanical weathering (Goldich, 1938), the latter leading to its abundance increasing with particle size. But quartz is also found, to a lower degree, in smaller sized dust particles (e.g., $11 \%$ volume fraction of $1.6 \mu \mathrm{m}$ sized particles over Morocco; Kandler et al., 2009).

The current paper focuses on the ice nucleation behavior at 238-242 K of airborne and surface-collected dust samples. We investigate ice nucleation at a constant temperature while $\mathrm{RH}$ is increased from ice saturation to above water saturation. While the partner paper (Boose et al., 2016c) showed that mineralogy explains most but not all of the observed ice nucleation behavior of desert dust, this paper focuses on the role of compounds other than the pure minerals for ice nucleation. We use thermogravimetric analysis and chemical imaging methods to highlight the effect of other entities mixed with the dust, such as organic material or soot, on the ice nucleation behavior. In addition to the samples studied in the partner paper (Boose et al., 2016c), three more airborne Saharan samples are investigated. Comparing the in total seven airborne Saharan samples to in situ measurements in the Saharan Air Layer, we find low variability in the ice nucleation behavior of dust from different sources. Furthermore, we show that airborne samples containing orthoclase are similarly active at the studied temperatures to those containing microcline.

\section{Methods}

\subsection{Dust sample origins and processing}

In this part of the series we present ice nucleation measurements of 18 dust samples. Seven airborne samples were collected after advection from the Sahara. Four of the airborne samples were collected directly from the air in August 2013 and 2014 at the Izaña observatory in Tenerife, Spain, using a custom-made large cyclone (Advanced Cyclone Systems, S.A.: flow rate of $200 \mathrm{~m}^{3} \mathrm{~h}^{-1}$ and $D_{50}=1.3 \mu \mathrm{m}$, the diameter at which the collection efficiency is $50 \%$ ). The remaining three airborne samples were collected by deposition on solar panels or roofs in April 2014 (Crete and Peloponnese, Greece) and on 10 May 2010 (Aburdees, Egypt). Nine samples were collected from the surface in the following deserts: (i) the Atacama desert in Chile; (ii) a location approximately $70 \mathrm{~km}$ from Uluru in Australia; (iii) the Great Basin in Nevada and (iv) the Mojave desert in California, USA; (v) a Wadi in the Negev desert, approximately $5 \mathrm{~km}$ from Sde Boker in Israel; (vi) dunes in the Sahara, close to Merzouga in Morocco; (vii) dunes in the Arabian desert in Dubai; (viii) the Etosha pan in Namibia, a dry salt pan; and (ix) the Taklamakan desert in China. A map showing the locations is provided in Boose et al. (2016c). Before arriving to the laboratory, samples were stored in various ways: Samples collected from the surface were typically stored for several weeks in PET bottles or other plastic containers. Airborne samples were stored in polypropylene tubes and sealed with paraffin wax tape. In the laboratory, all samples were stored in the dark at room temperature in polypropylene tubes after pre-processing (sieving and milling, see below). While changes in the ice nucleating ability due to water uptake, loss of volatile material, or growth of biological material which may occur during storage cannot be excluded, they are assumed to be minor, because the samples were collected and stored under dry conditions, hardly exposed to air, and kept at a lower temperature than at which they were collected. The Israel sample and the Etosha sample are from the same batch as those studied in Kaufmann et al. (2016). The surfacecollected samples were sieved with a cascade of dry sieves (Retsch Vibratory Sieve Shaker AS 200) with $32 \mu \mathrm{m}$ diameter being the smallest cutoff size. Most samples only contained a few weight percent in this size range. The Australia 
and Morocco samples were milled using a vibratory disc mill (Retsch, model RS1), as the fraction of particles in the sub$32 \mu \mathrm{m}$ size range was too low for ice nucleation experiments. Particles in the lowest available size bin $(32-64 \mu \mathrm{m})$ of the Morocco sample were milled. The Australia sample was first sieved with a coarse, millimeter-range sieve to separate any large material, and the remaining smaller fraction was milled. For the Israel and the Atacama dusts, a sieved and a milled sample were included in the study. The Israel sample was first sieved, and part of a sub- $32 \mu \mathrm{m}$ fraction was milled, while in case of the Atacama sample part of the initial, unsieved batch was milled.

To investigate if the ice nucleation activity of the samples is influenced by biological particles internally or externally mixed with the dust or by organic coatings on the dust particle surface, selected samples were heated to $300^{\circ} \mathrm{C}$ and stayed at this temperature for $10 \mathrm{~h}$ before the ice nucleation experiments. At this temperature proteinaceous material, such as bacterial and fungal INPs, should be denatured (Pouleur et al., 1992), and the majority of organic material, such as glucose, is combusted and evaporated (Kristensen, 1990, and references therein).

\subsection{Dust particle generation and size distribution}

Dust particles were dry dispersed using a rotating brush generator (RBG, Palas, model RBG 1000) with $\mathrm{N}_{2}$ (5.0) as carrier gas into a $2.78 \mathrm{~m}^{3}$ stainless steel aerosol reservoir tank (Kanji et al., 2013) via a cyclone that confined the dust size distribution to below $D_{50}=2.5 \mu \mathrm{m}$. Total particle concentration was monitored using a condensation particle counter (CPC; TSI model 3772). The tank was filled with particles up to a concentration of $1200 \mathrm{~cm}^{-3}$, which decreased steadily to about $300 \mathrm{~cm}^{-3}$ over approximately $10 \mathrm{~h}$. The tank was cleaned before an experiment by repeatedly evacuating and purging it with $\mathrm{N}_{2}$ until the particle concentration decreased to $30-90 \mathrm{~cm}^{-3}$.

The particle size distribution of all samples was measured with a scanning mobility particle sizer (SMPS; TSI; DMA model 3081, CPC model 3010$)$ for mobility diameters $\left(d_{\mathrm{m}}\right)$ between 12 and $615 \mathrm{~nm}$ and an aerodynamic particle sizer (APS; TSI; model 3321) for aerodynamic diameters $\left(d_{\text {aer }}\right)$ between 0.5 and $20 \mu \mathrm{m}$. The mobility and aerodynamic diameters were converted to volume equivalent diameter $\left(d_{\mathrm{ve}}\right)$ by assuming a typical dust particle density of $\rho=2.65 \mathrm{~g} \mathrm{~cm}^{-3}$ (Hinds, 1999; Kandler et al., 2007; Hiranuma et al., 2015a) and optimizing the shape factor $\chi$ to receive the best overlap of two size distributions measured by the SMPS and APS. This yielded $\chi=1.36$, which is in the range of earlier studies (Hinds, 1999; Alexander, 2015; Hiranuma et al., 2015a). Assuming spherical particles, the area size distribution was calculated and fitted with a bimodal log-normal distribution. The mean particle surface area $\left(\overline{A_{\mathrm{ve}, \mathrm{w}}}\right)$ was calculated from the resulting fit for each sample. Four size distributions and the fit parameters for all samples are provided in Boose et al. (2016c). During an experiment $\overline{A_{\mathrm{ve}, \mathrm{w}}}$ was reduced by between $6 \%$ to $24 \%$ due to a faster sedimentation of larger particles in the aerosol tank. The Great Basin sample was coarser than the other samples and settled out faster. Therefore two refills were necessary, and $\overline{A_{\mathrm{ve}, \mathrm{w}}}$ varied by $64 \%$.

\subsection{Mineralogical, thermogravimetric, and morphology analysis}

The quantitative mineralogical composition of the bulk dust samples was investigated with the X-ray diffraction (XRD) Rietveld method (Rietveld, 1969) using a Bragg-Brentano diffractometer (Bruker AXS D8 Advance with $\mathrm{Cu} \mathrm{Ka}$ radiation). The qualitative-phase composition was determined with the software DIFFRACplus (Bruker AXS). On the basis of the peak positions and their relative intensities, the mineral phases were identified in comparison to the PDF-2 database (International Centre for Diffraction Data). The quantitative composition was calculated by means of Rietveld analysis of the XRD pattern (Rietveld program AutoQuan, GE SEIFERT; Bergmann et al., 1998; Bish and Plötze, 2011). Due to the small amount of the dust sample, it was not possible to do a mineralogical analysis of the identical size fraction as in the tank $(<2.5 \mu \mathrm{m})$. Instead, the entire size fraction of the airborne and the milled samples, and the sub- $32 \mu \mathrm{m}$ fraction of the sieved samples, was used. The measured mineralogical composition is provided in Boose et al. (2016c), and that of the additional Tenerife samples is provided in Table 1. The Tenerife2014_1 sample was additionally measured by Powder XRD (Panalytical XPert Pro) in Bragg-Brentano geometry, equipped with a copper anode providing $\mathrm{Cu} \mathrm{Ka}$ radiation. A diffractogram was recorded before and after heating the sample to $300^{\circ} \mathrm{C}$ for $10 \mathrm{~h}$ on a silicon sample carrier.

Thermogravimetric analysis (TGA) of six of the dust samples was conducted by gradually heating the dust samples from 40 to $300^{\circ} \mathrm{C}$ at $10 \mathrm{~K} \mathrm{~min}^{-1}$ and continuously recording the mass of the samples in a thermogravimetric analyzer (Model Pyris 1 TGA, PerkinElmer). During the temperature scan, the samples were under a constant nitrogen flow of $20 \mathrm{~mL} \mathrm{~min}^{-1}$.

The morphology of one sample was investigated using scanning electron microscopy (SEM; FEI Quanta 250 FEG, ThermoFisher Scientific).

\subsection{Chemical imaging: ATR spectrometry and Raman mapping}

Attenuated total reflection infrared (ATR-IR) spectroscopy was carried out on an FTIR (Bruker Vertex 80v) equipped with an ATR cell (Pike GladiATR, diamond ATR crystal). The beam path of the spectrometer and the optical parts of the ATR cell are under a vacuum $(1.65 \mathrm{mbar})$ to minimize the influence of water vapor and $\mathrm{CO}_{2}$. The crystal where the sample is placed sits in a cell that is flushed with nitrogen gas before and through the measurement for the same rea- 
Table 1. Mineralogical composition in wt \% of airborne Saharan dust samples. Crete, Egypt, Tenerife2013 (Tenerife in Part 1), and Peloponnese as in Boose et al. (2016c). Results were rounded to the nearest integer from the original Rietveld fit results, thus total composition $\neq 100$ wt $\%$ may occur.

\begin{tabular}{lrrrrrrr}
\hline Mineral & Crete & Egypt & Tenerife2013 & Tenerife2014_1 & Tenerife2014_2 & Tenerife2014_3 & Peloponnese \\
\hline Calcite & 25 & 29 & 7 & 4 & 6 & 6 & 33 \\
Chlorite & 4 & 8 & 2 & 3 & 2 & 1 & 3 \\
Dolomite & 3 & 8 & 2 & 2 & & 2 & 5 \\
Gypsum & 4 & 6 & 2 & 1 & 3 & 2 & \\
Halite & 1 & 4 & & 2 & 1 & \\
Hematite & 1 & & 1 & 2 & 1 & 1 & 1 \\
Illite & & & 6 & 16 & 7 & 9 & 13 \\
Kaolinite & 12 & 11 & 16 & 18 & 13 & 14 & 8 \\
Microcline & & & 4 & 7 & 7 & 5 & 5 \\
Muscovite & 9 & 8 & 7 & 4 & 3 & 3 & 5 \\
Orthoclase & 5 & 4 & & 2 & 6 & 5 & 5 \\
Palygorskite & 5 & & 2 & 4 & 32 & 30 & \\
Plagioclase & 7 & & 32 & 13 & 13 & 14 & 18 \\
Smectite & & & 14 & 12 & & \\
Quartz & 23 & 23 & & & & \\
\hline
\end{tabular}

son. A liquid-nitrogen-cooled MCT detector is used for spectra acquisition. Spectra of the samples were recorded before and after a heat treatment. For the heat treatment the samples were placed for $10 \mathrm{~h}$ into a laboratory oven at $300^{\circ} \mathrm{C}$. The spectral window was set between 700 and $4000 \mathrm{~cm}^{-1}$, with a resolution of $1 \mathrm{~cm}^{-1}$. Spectra for the Tenerife2014_1, Etosha, and Australia samples were recorded this way. Raman images were recorded on a confocal Raman spectrometer (WITec alpha300 RSA+) using a $488 \mathrm{~nm}$ laser, 50 $\times$ magnification, grating of 600 lines per millimeter, and a laser power of $4.7 \mathrm{~mW}$. For Raman imaging the dust was impacted on a clean aluminium surface as described in Ofner et al. (2017) and subsequently mapped with the aid of a Piezo XY stage. Raman mappings were carried out before and after the same heat treatment as that for the ATR-IR measurements. The Etosha and Australia samples were mapped with this method.

\subsection{Deposition and condensation nucleation experiments and data treatment}

Ice nucleation experiments were conducted with the portable ice nucleation chamber (PINC; Chou et al., 2011; Boose et al., 2016a). Aerosol particles are sampled from the tank, dried, and introduced into the chamber, where they are layered between two particle-free sheath air flows. Before an experiment, the two chamber walls are coated with a thin layer of ice. During an experiment a temperature gradient is applied between the walls, leading to diffusion of water vapor and heat. A linear gradient of temperature and the partial pressure of water vapor between the walls leads to supersaturation with respect to ice. At a constant aerosol layer temperature, the $\mathrm{RH}$ is raised at a constant rate until supersaturation with respect to water of a few percent $\left(\mathrm{RH}_{\mathrm{w}}=103 \%-\right.$
$105 \%)$ is reached. If ice nucleation occurs under these conditions, ice crystals grow on the INPs and are detected in the lower part of the chamber by an optical particle counter. As the ice nucleation mechanisms cannot be identified visually in the PINC we refer to the deposition mode at $\mathrm{RH}_{\mathrm{w}}<100 \%$ and to condensation freezing at $\mathrm{RH}_{\mathrm{w}}>100 \%$. We use these relative-humidity-based thermodynamic regimes as an operational definition, which does not exclude the possibility of PCF to occur at $\mathrm{RH}_{\mathrm{w}}<100 \%$ (Marcolli, 2017). Condensation mode refers here to the conditions above water saturation where full droplet activation prior to freezing cannot be guaranteed.

In the deterministic concept (Langham and Mason, 1958) ice nucleation is assumed to take place at so-called ice nucleation active sites on the particle's surface (Vali, 1966). The probability of such a site being present on a particle and thus of the particle to nucleate ice at a certain temperature scales with the particle's surface area (Archuleta et al., 2005; Connolly et al., 2009; Welti et al., 2009). To account for this dependency and compare the ice nucleation ability of the different dust samples the ice-active surface site density $n_{\mathrm{s}}$ was calculated:

$n_{\mathrm{s}}=-\frac{\ln (1-\mathrm{AF})}{\overline{A_{\mathrm{ve}, \mathrm{w}}}} \approx \frac{\mathrm{INP}}{N_{\mathrm{tot}} \overline{A_{\mathrm{ve}, \mathrm{w}}}}$,

with the total particle concentration $N_{\text {tot }}$ and the activated fraction AF given by INP/ $N_{\text {tot }}$. The approximation is only valid for $\mathrm{AF}<0.1$, which is the case in this study. As aerosol particles larger than $1 \mu \mathrm{m}$ were in the size range of the ice crystals and could not be differentiated based on size in the optical particle counter spectra, the $n_{\mathrm{s}}$ was corrected by subtracting the average $n_{\mathrm{s}}$ at $\mathrm{RH}_{\mathrm{i}}=100 \%$ to $103 \%$. At these low $\mathrm{RH}_{\mathrm{i}}$ values no ice nucleation is expected, thus counts in 
the size range of ice crystals are assumed to be large dust particles.

The ice nucleation activity of the Australia, Atacama milled, Etosha, Tenerife2014_1, Peloponnese, and Morocco samples was additionally measured after they had been exposed to $300^{\circ} \mathrm{C}$ for $10 \mathrm{~h}$. For these experiments the tank was not used. Instead, dust was dry dispersed using particlefree air from a sonicated flask via a cyclone with a cutoff of $2.5 \mu \mathrm{m}$ and a diffusion dryer into a PINC, a CPC, an APS, and a SMPS. The unheated samples were additionally measured with the same setup to allow direct comparison. The $n_{\mathrm{s}}$ measured with the tank setup, in comparison to the sonicated flask setup for the unheated samples, varied between a factor of $1 / 3$ to 3 , which is a good agreement given the limitations of $n_{\mathrm{s}}$ as a comparison parameter (Hiranuma et al., 2015b, 2018). Possible reasons for the differences are the sonicated flask breaking up larger entities, thus leading to a different mineralogy per size bin than the rotating brush generator or uncertainties stemming from the use of a different measurement setup. This shows the limits of using $n_{\mathrm{s}}$ for such complex, polydisperse samples, which should ideally remove any size dependency. To reduce setup dependent uncertainty, only results measured with the same measurement setup are compared in the following discussion.

\section{Results and discussion}

\subsection{Ice nucleation in the deposition and condensation mode and dust mineralogy}

Ice-active surface site density was determined for 18 dust samples, of which four are from the Sahara and were collected after atmospheric transport at the Izaña observatory in Tenerife and three were from after atmospheric transport in the Peloponnese, in Crete, and the Sinai Peninsula in Egypt. Figure 1 shows RH scans at three temperatures for these Saharan samples together with RH scans measured online at the Izaña observatory during the Cloud Affecting particLes In Mineral dust from the sAhara (CALIMA) campaigns in August 2013 and 2014, when the observatory was located in the Saharan Air Layer. The data and description of the location and campaigns are given in Boose et al. (2016b). The online and offline measured $n_{\mathrm{S}}$ values agree well. Most of the $n_{\mathrm{S}}$ curves of the different Saharan samples span an order of magnitude. In Fig. 2 a scatter plot of $\ln \left(n_{\mathrm{s}}\right)$ at $\mathrm{RH}_{\mathrm{w}}=102 \%$ against the quartz plus feldspar content of the dust samples is shown, which is discussed in more details below. It reveals that the airborne Saharan samples are similar in $n_{\mathrm{S}}$ and their quartz plus feldspar fraction ( $20 \mathrm{wt} \%-30 \mathrm{wt} \%)$. This holds true for most other mineral components, as shown in Table 1 . The biggest differences are found for smectite and calcite, the latter accounting for $25 \mathrm{wt} \%-33 \mathrm{wt} \%$ in the Crete, Egypt, and Peloponnese samples but only for $4 \mathrm{wt} \%-7 \mathrm{wt} \%$ in the Tenerife samples. Smectite, in contrast, was only found
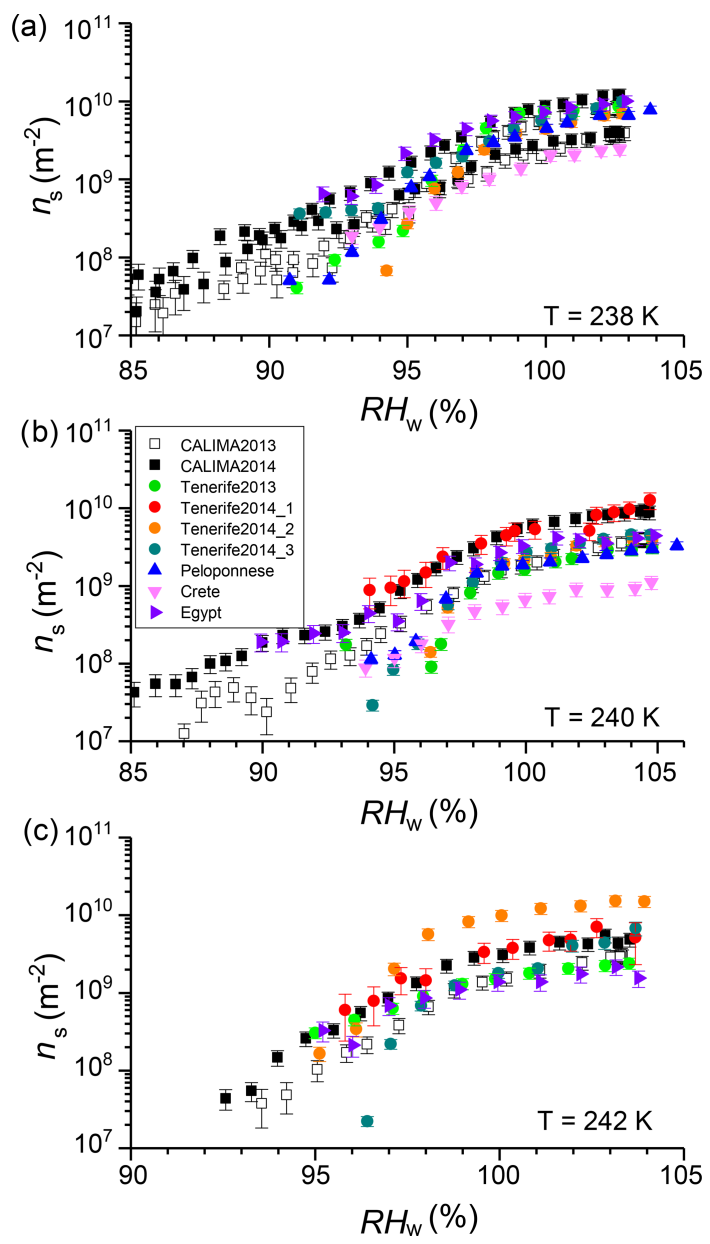

Figure 1. Ice-active surface site density at (a) $238 \mathrm{~K}$, (b) $240 \mathrm{~K}$, and (c) $242 \mathrm{~K}$ of samples collected airborne at the Izaña observatory on Tenerife in 2013 and 2014 (circles), in Egypt, Crete, and Peloponnese (triangles), and $n_{\mathrm{S}}$ measured in situ during the CALIMA 2013 and 2014 campaigns which took place at the Izaña observatory.

in the Tenerife samples (23 wt \%-32 wt \%) and not in dust from the other three locations. Smectite and calcite are both known to have low ice nucleation activity (Atkinson et al., 2013; Kaufmann et al., 2016). Thus, the similar amount of one or the other mineral in all Saharan dust samples is in line with the observed similar $n_{\mathrm{s}}$. Differentiating between microcline and orthoclase and comparing the bulk mineralogy to the surface-dependent ice nucleation ability introduces uncertainty. Within this uncertainty, there is no detectable effect from the presence of microcline versus orthoclase in the airborne samples at the studied temperatures. This is in line with the findings by Whale et al. (2017) that there is no correlation between ice nucleating ability and the level of ordering in the aluminosilicate framework, which determines if orthoclase (less ordered) or microcline (more ordered) is present.

To determine how well the dust mineralogy can overall predict the ice nucleation activity, the correlation of $\ln \left(n_{\mathrm{s}}\right)$ with the fractions of the most common minerals in the 
Table 2. Overview of the Pearson correlation coefficients of the sum of selected mineral fractions and $\ln \left(n_{\mathrm{S}}\right)$ at different temperatures. An asterisk indicates that the correlation was significant at the 0.05 level. K-feldspar comprises microcline and orthoclase, while feldspar refers to the sum of microcline, orthoclase, and plagioclase. The number of samples included in each correlation varies, because the $n_{\mathrm{S}}$ of the Mojave, Peloponnese, and Tenerife2014_2 samples was below the detection limit at $242 \mathrm{~K}$, and the size distribution measurements of the Tenerife2014_1 sample were corrupted for the RH scan at $238 \mathrm{~K}$.

\begin{tabular}{lrrrrrr}
\hline$T$ & $238 \mathrm{~K}$ & $240 \mathrm{~K}$ & $242 \mathrm{~K}$ & $238 \mathrm{~K}$ & $240 \mathrm{~K}$ & $242 \mathrm{~K}$ \\
$\mathrm{RH}_{\mathrm{w}}$ & $97 \%$ & $97 \%$ & $97 \%$ & $102 \%$ & $102 \%$ & $102 \%$ \\
Number of samples & 18 & 19 & 16 & 18 & 19 & 16 \\
\hline K-feldspar & 0.02 & 0.03 & -0.06 & -0.08 & -0.07 & -0.13 \\
Feldspar & 0.15 & 0.08 & 0.05 & 0.05 & -0.09 & -0.17 \\
Quartz & $0.63^{*}$ & $0.52^{*}$ & 0.47 & $0.71^{*}$ & $0.74^{*}$ & $0.71^{*}$ \\
Illite & -0.14 & -0.15 & 0.11 & -0.01 & -0.04 & 0.13 \\
Kaolinite & $-0.66^{*}$ & $-0.56^{*}$ & -0.41 & $-0.51^{*}$ & -0.35 & -0.19 \\
Feldspars + quartz & $0.64^{*}$ & $0.5^{*}$ & 0.44 & $0.63^{*}$ & $0.56^{*}$ & 0.49 \\
Feldspars + quartz + illite & $0.63^{*}$ & $0.49^{*}$ & 0.47 & $0.65^{*}$ & $0.58^{*}$ & $0.53^{*}$ \\
Feldspars + quartz + kaolinite & $0.51^{*}$ & 0.40 & 0.35 & $0.54^{*}$ & $0.51^{*}$ & 0.48 \\
Feldspars + quartz + illite + kaolinite & $0.50^{*}$ & 0.38 & 0.37 & $0.55^{*}$ & $0.51^{*}$ & 0.51 \\
Calcite & -0.12 & 0.05 & -0.22 & -0.31 & -0.26 & -0.32 \\
\hline
\end{tabular}

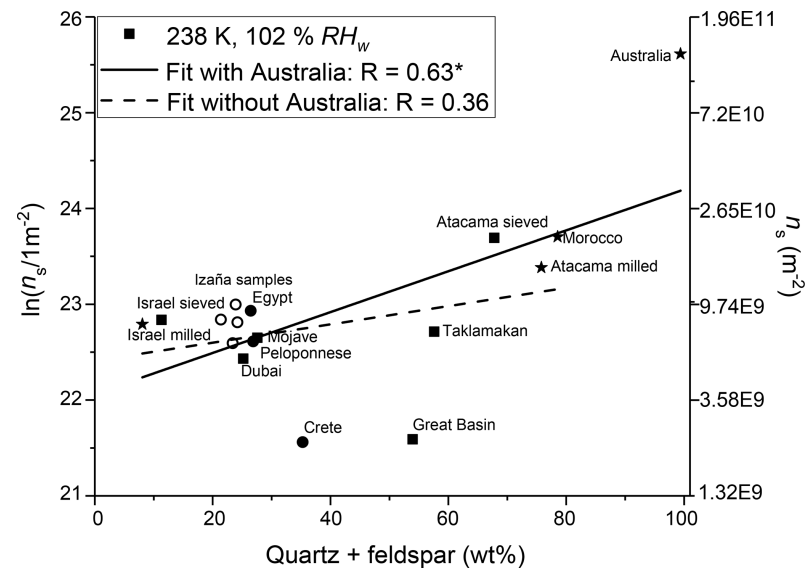

Figure 2. Natural log of the ice-active surface site density as a function of the sum of quartz and feldspar content of the samples. Square symbols indicate surface-collected samples, stars indicate milled samples, and circles indicate airborne samples. For clarity, the Tenerife samples are not named individually and are instead shown as open circles. The asterisk in the legend indicates that the correlation is significant at the 0.05 level.

dust samples was compared in the partner paper (Boose et al., 2016c). This comparison showed that the immersionmode ice nucleation activity correlates best with the Kfeldspar fraction alone at $T=253 \mathrm{~K}$, a temperature where only feldspar minerals are found to have significant ice nucleation activity (Atkinson et al., 2013). At $T \leq 245 \mathrm{~K}$, the ice nucleation activity correlates best with the quartz and quartz + feldspar fractions of the dust samples (Boose et al., 2016c). At these lower temperatures, quartz as well as, to a lower degree, clay minerals were found to nucleate ice efficiently (Atkinson et al., 2013). Before investigating the role of other compounds, here we do a similar correlation analysis of the $\ln \left(n_{\mathrm{S}}\right)$ at $T=238,240$, and $242 \mathrm{~K}$ and $\mathrm{RH}_{\mathrm{w}}=97 \%$ and $102 \%$ with the fraction of various minerals contained in the dust samples. Figure 2 exemplarily shows a scatter plot of $\ln \left(n_{\mathrm{s}}\right)$ at $\mathrm{RH}_{\mathrm{w}}=102 \%$ against the quartz plus feldspar content of the dust samples. The Etosha sample was excluded from the correlation, as it does not contain any significant amount of these minerals. The surface-collected samples with a high ratio of quartz and feldspar tend to have a higher $n_{\mathrm{s}}$ than the airborne samples. This trend is similar at the three investigated temperatures. The resulting correlation coefficients for the investigated mineral fractions are provided in Table 2. The findings by Boose et al. (2016c) for the immersion mode $n_{\mathrm{S}}$ are confirmed in the deposition and condensation mode: at all three tested temperatures, the highest correlation of $n_{\mathrm{s}}$ is found for the fraction of quartz, followed by the quartz + feldspar fraction. The correlation with quartz alone is dominated by the Australia sample, which consists of $91 \mathrm{wt} \%$ quartz and is by far the most ice nucleation active dust sample. The remaining samples, which consist of, at most, $64 \mathrm{wt} \%$ of quartz, correlate only weakly with quartz alone (e.g., $R=0.29, p=0.27$, at $T=238 \mathrm{~K}$ and $\left.\mathrm{RH}_{\mathrm{w}}=102 \%\right)$ and better with quartz plus feldspar $(R=$ $0.41, p=0.08$ ). Adding illite to the quartz + feldspar fraction leads to insignificant changes of the correlation coefficient while adding kaolinite reduces it. Calcite and kaolinite alone are always negatively correlated with $n_{\mathrm{s}}$ in both deposition and condensation mode. These observations are reasonable when compared to the findings of Atkinson et al. (2013), who found a higher $n_{\mathrm{s}}$ for quartz over clay minerals at $T>236 \mathrm{~K}$ but lower $n_{\mathrm{s}}$ for quartz than for feldspars for $T>242 \mathrm{~K}$. Generally, the correlations are lower in this study compared to the immersion-mode data from Boose et al. (2016c). A possible reason for this is that the only par- 

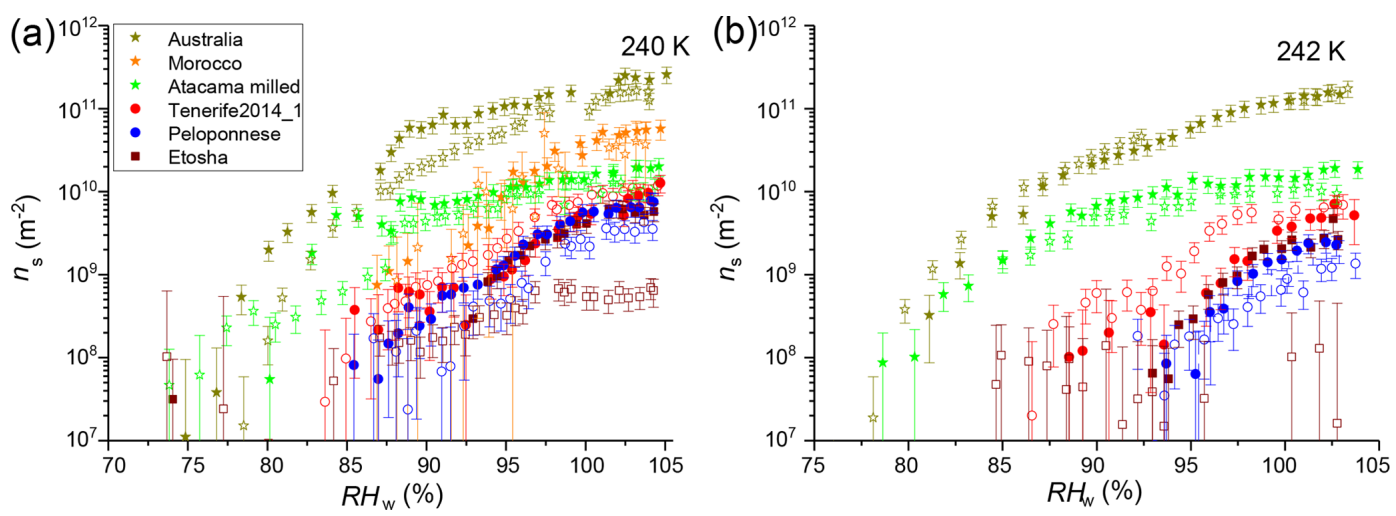

Figure 3. Ice-active surface site density at (a) $240 \mathrm{~K}$ and (b) $242 \mathrm{~K}$ of samples before (filled symbols) and after (open symbols) heat treatment. Error bars include the Poisson error of the INP measurements and the maximum variation of $\overline{A_{\mathrm{ve}, \mathrm{w}}}$. Square symbols indicate surface-collected samples, stars indicate milled samples, and circles indicate airborne samples.

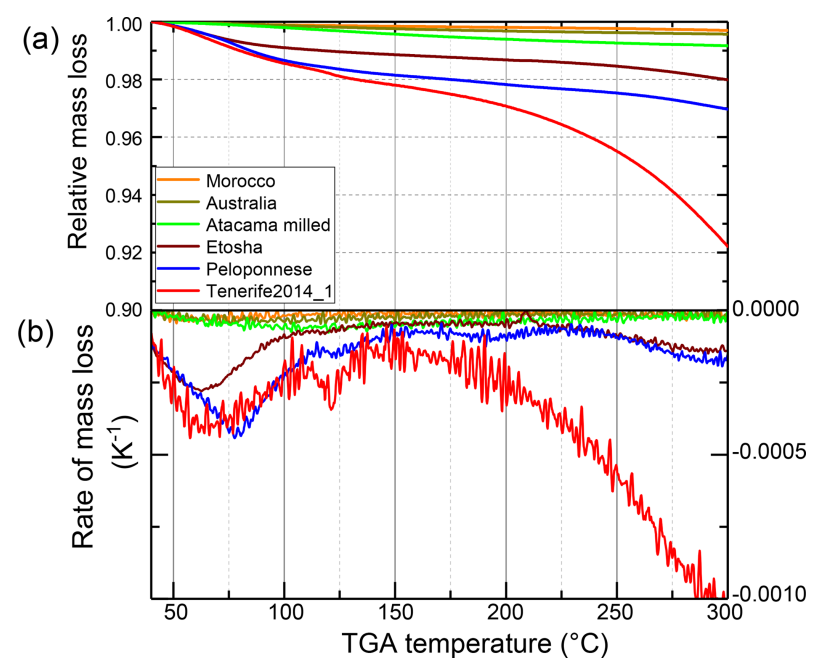

Figure 4. Relative mass loss (a) and its derivative (b) under heating of the different dust samples.

tial activation of INPs at these measurement conditions in the PINC due to an inhomogeneous $\mathrm{RH}$ profile along the particle trajectories inside the chamber (Garimella et al., 2017) weakens the effect of differences in mineralogy. Another reason could be that surface coatings play a more prominent role at lower RH values, because they are less diluted than in immersion mode. Correlating mineralogy, which is based on the bulk fraction, with the surface property $n_{\mathrm{s}}$, leads to additional uncertainty, as described above. Effects by non-mineral substances such as coatings are discussed in the following.

\subsection{Ice nucleation and heat labile material}

In this section, the role of heat labile material on the surface of dust particles is investigated. A representative subset of the samples was selected to reduce the number of experiments necessary. The Australia and Morocco sample were selected because of their exceptional high $n_{\mathrm{s}}$, the Etosha sample because its mineralogy did not explain the observed $n_{\mathrm{s}}$, the Atacama milled sample because we expected a higher $n_{\mathrm{s}}$ from the mineralogy, and finally the Tenerife2014_1 and Peloponnese samples as representatives for two airborne samples from different locations. Figure 3 shows the $n_{\mathrm{s}}$ at 240 and $242 \mathrm{~K}$ of the unheated and the heated samples. In case of the Tenerife2014_1 sample the heat treatment led to an increase of $n_{\mathrm{s}}$ at $\mathrm{RH}_{\mathrm{w}}<100 \%$, while it had no effect above water saturation. In contrast, the maximum $n_{\mathrm{S}}$ of the Etosha sample decreased by 1 order of magnitude at $240 \mathrm{~K}$ after heating. At $242 \mathrm{~K}$ the $n_{\mathrm{S}}$ was below the detection limit, as can be seen by a scattered flat $n_{\mathrm{S}}$ curve in Fig. $3 \mathrm{~b}$. The heating had a small decreasing effect on the $n_{\mathrm{s}}$ of the Peloponnese sample at all $\mathrm{RH}$ values and little to no significant effect on the $n_{\mathrm{s}}$ of the remaining samples. A change in ice nucleation ability due to the heating gives an indication of the nature of the active sites, i.e., if they are inherent to the minerals themselves or a semi-volatile coating material or are due to biological particles, which are impacted by the heating. An RH dependency of the change in ice nucleation ability may suggest that the material which contains or coats the active sites is susceptible to dissolution.

We investigated these possible implications further by thermogravimetric analysis, ATR-IR, and Raman spectroscopy of the samples. The relative mass loss under increasing temperature is shown in Fig. 4a and its first derivative in Fig. 4b. If pure samples of single minerals or organic species were studied, the TGA would show discrete steps in mass loss, indicated by spikes in the derivative plot. However, the complexity of the dust samples in this study, which consist of 
several minerals and likely also various other components, cause the spikes to widen, thus reducing the possibility to observe discrete steps. For example, Xi et al. (2004) showed that the mixture of a montmorillonite with varying concentrations of organic surfactant shifts the peak in the derivative mass between the higher temperature of the montmorillonite and the lower temperature of the surfactant, depending on the concentration of the surfactant. This makes it impossible to identify exactly which species are evaporated at which temperature. However, taking into account the temperature range, a qualitative analysis is possible.

The Morocco, Australia, and Atacama milled samples, which all showed no change in $n_{\mathrm{S}}$ after heating, exhibit a small, gradual decrease in mass of, at maximum, $0.5 \%$ between 40 and $300^{\circ} \mathrm{C}$. In the case of the three samples whose $n_{\mathrm{s}}$ changed after heating, i.e., the Etosha, Peloponnese, and Tenerife2014_1 samples, a larger mass loss is found. A first decrease in mass of about $1 \%$ (Etosha) to $2 \%$ (both airborne samples) is observed between 40 and $110^{\circ} \mathrm{C}$. The Etosha sample shows a second graduate mass release from $220^{\circ} \mathrm{C}$ onwards (1\%). The two airborne samples, Peloponnese and Tenerife2014_1, show small steps in mass release between 110 and $225^{\circ} \mathrm{C}$ and 110 and $170^{\circ} \mathrm{C}$, respectively, and a continuous reduction in mass above these temperatures, reaching a total loss of $3 \%$ and $8 \%$ at $300{ }^{\circ} \mathrm{C}$, respectively.

The temperature ranges where the mass loss occurs can be related to different materials which were evaporated and potentially altered the ice nucleation behavior. The first decrease in mass at 40 to $110^{\circ} \mathrm{C}$ is mostly due to the evaporation of adsorbed water on the surface of the dust particles or of volatile material such as volatile organics. At temperatures between 110 and $300^{\circ} \mathrm{C}$ the mass loss is mainly related to decomposition of organic matter, e.g., amides, carboxylic, and phenolic functional groups (Miyazawa et al., 2000) or the combustion of certain organic compounds such as cellulose (Stamm, 1956; Lipska and Parker, 1966). Kristensen (1990) studied various biogenic organic materials, such as cellulose, glucose, bacteria (Escherichia coli and bacillus subtilis), and humic and glutamic acid, which showed either a bimodal or trimodal pattern in the TGA derivative. For all samples, they observed a first peak at $160-180^{\circ} \mathrm{C}$, which accounted for $10 \%-42 \%$ of the mass loss and a second mass loss peak between 340 and $490^{\circ} \mathrm{C}$. Most minerals present in the dust samples are stable at $T \leq 300^{\circ} \mathrm{C}$, apart from smectite and gypsum (Földvári, 2011), as further discussed below.

We performed ATR-IR spectroscopy on the Etosha and Tenerife2014_1 to investigate the nature of the material responsible for the respective decrease and increase in $n_{\mathrm{S}}$ with heating. Furthermore, we chose the Australia sample as representative for most other cases where the $n_{\mathrm{s}}$ stayed the same. Figure 5 shows the ATR-IR spectra of the three samples before and after heating. The bands between wavenumber 700 to $1200 \mathrm{~cm}^{-1}$ are related to the dominant minerals in the (bulk) samples: quartz in case of the Australia sample; dolomite, calcite, and ankerite in the case of Etosha; and
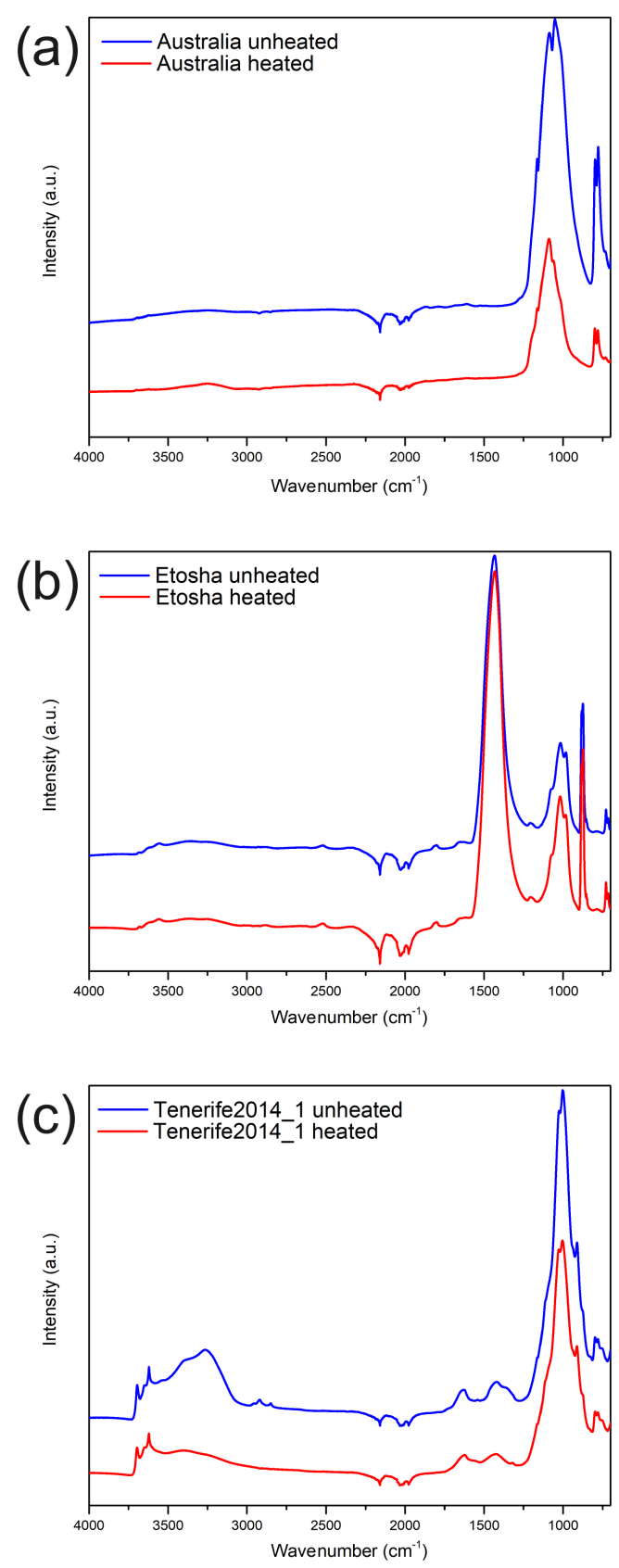

Figure 5. Attenuated total reflectance infrared (ATR-IR) spectra for the (a) Australia, (b) Etosha, and (c) Tenerife2014_1 samples before (blue) and after heating (red).

kaolinite and smectite in case of the Tenerife2014_1 sample. Kaolinite also has signals at 3619,3650 , and $3685 \mathrm{~cm}^{-1}$ (Lafuente et al., 2015). No significant differences are observed between the unheated and the heated Australia and Etosha samples. The intensity differences in the mineral bands are likely related to single grains not representatively amplifying the signal during sampling. The Tenerife2014_1 sample, in contrast, shows clear differences before and after heating. A loss of intensity in the $\mathrm{OH}$ stretch region between 3500 
and $3100 \mathrm{~cm}^{-1}$ is observed, which is too pronounced to be from adsorbed water only. Further intensity loss is observed in the $\mathrm{C}-\mathrm{H}$ aliphatic region, with decreasing bands between 3000 and $2850 \mathrm{~cm}^{-1}$. This points to volatile organics being present on the unheated sample which were released during heating.

Raman mapping was performed on the Etosha, Tenerife2014_1, and Australia samples. Due to strong fluorescence, however, the Tenerife2014_1 spectra did not yield any information and are thus not presented here. The Raman maps for the Etosha and Australia samples are shown in Fig. 6. They reveal bands between 1200 and $1700 \mathrm{~cm}^{-1}$ with a distinctive pattern related to soot and carbonaceous material (Sadezky et al., 2005) being present on many particles in the Australia sample (Fig. 6a2 and a4) and on some in the Etosha sample (Fig. 6c2 and c4). The carbonaceous material is not affected by the heating (Fig. 6b and d). A cluster with a strong broad signal at $3180 \mathrm{~cm}^{-1}$ and a secondary band at around $1080 \mathrm{~cm}^{-1}$ is observed for the unheated Etosha sample, which is present on most particles (Fig. 6c1 and c3). After the heat treatment, no cluster is identified anymore containing the broad $3180 \mathrm{~cm}^{-1}$ band, yet the signal at $1080 \mathrm{~cm}^{-1}$ remains. This supports the interpretation that the band at $1080 \mathrm{~cm}^{-1}$ can be attributed to calcite. Furthermore, the band at $1080 \mathrm{~cm}^{-1}$ does not correlate with the $3180 \mathrm{~cm}^{-1}$ band, therefore they belong to two different compounds. The cluster analysis groups these signals for the unheated sample due to the spatial proximity of the materials on the dust. It is likely that on mineral dust grains with a high calcite content a compound was absorbed. During the heat treatment this absorbed compound disappeared and the calcite remained. Afterwards, the cluster analysis showed no group containing the $3180 \mathrm{~cm}^{-1}$ band. A filter $\left(3180 \pm 175 \mathrm{~cm}^{-1}\right)$ was applied to search specifically for this signal. This revealed only very few particles carrying the related material after heating (Fig. 6d1 and d3).

Identification of the material which was released or decomposed during the heating was hampered by fluorescence inherent to the minerals in the samples and also possibly due to biological material if present in the unheated samples. The ratio of signal to noise (fluorescence) was optimized by impacting small amounts of the samples on a pure aluminum surface and by adjusting the laser power, but the fluorescence could not be entirely suppressed. This, together with the complexity of the samples, inhibited an unambiguous identification of the species which were altered by the heating and may affect the ice nucleation ability. We suggest three possible candidates for the cluster with a strong Raman signal at $3180 \mathrm{~cm}^{-1}$ in the Etosha sample. (a) Amides typically show a Raman signal between 3300 and $3100 \mathrm{~cm}^{-1}$ (Socrates, 2001), as observed in the Etosha sample, but distinct peaks are usually also observed for amides between 1700 and $1600 \mathrm{~cm}^{-1}$, which are absent in the Etosha sample. (b) Pure ammonium sulfate has a broad band above $3000 \mathrm{~cm}^{-1}$ and a sharp peak at around $990 \mathrm{~cm}^{-1}$ (Bertram et al., 2011). While the broad band at $3180 \mathrm{~cm}^{-1}$ agrees well with the observed signal, a second band is found at $1080 \mathrm{~cm}^{-1}$ in the Etosha sample. Ammonium sulfate has a band at $990 \mathrm{~cm}^{-1}$, which is significantly different from $1080 \mathrm{~cm}^{-1}$. Thus, the signal can be attributed to the calcite which has a very prominent band at this position. In addition, the XRD measurements confirmed calcite to be present in the sample. (c) Cellulose shows a broad band between 3575 and $3125 \mathrm{~cm}^{-1}$ and numerous bands between 1320 and $1030 \mathrm{~cm}^{-1}$ (Socrates, 2001). Additional bands at 1750 and $1725 \mathrm{~cm}^{-1}, 1635$ and $1600 \mathrm{~cm}^{-1}$, and 1480 and $1435 \mathrm{~cm}^{-1}$ are not distinguishable in the Etosha Raman spectrum.

For the Etosha sample an effect of organic or other heat labile material on the ice nucleation behavior appears likely. The main minerals contained in the Etosha sample (i.e., ankerite, calcite, dolomite, and muscovite) are not known to be particularly ice nucleation active at the investigated temperatures. In case of ankerite the ice nucleation ability is unknown. Based on its similarity with dolomite, a carbonate known not to be ice nucleation active, it is assumed that ankerite is also not active. Thus, one of the suggested candidates with the strong Raman signal at $3180 \mathrm{~cm}^{-1}$ is likely responsible for the ice nucleation activity of the Etosha sample. Being part of proteins, amides are ubiquitous in nature. Similarly, cellulose is the most abundant organic compound on Earth (Kamide, 2005) amongst others as a structural component of algae. Both cellulose (Hiranuma et al., 2015b) and some proteins (Maki et al., 1974) have been identified to cause ice nucleation at the studied temperatures. Ammonium sulfate has been observed to correlate with higher INP concentration in Saharan dust (Boose et al., 2016b) and to increase the freezing onset temperature of microcline (Kumar et al., 2018a) and various other minerals (Whale et al., 2018) by up to $3 \mathrm{~K}$. According to a study on the Ntwetwe Pan in Botswana by Thomas et al. (2014), the organic carbon concentration in a salt pan is about $1 \mathrm{wt} \%$ at the surface and consists of cyanobacteria and algae. We assume that similar values apply also for the Etosha pan. The Etosha sample was collected from the edge of the salt pan, a few hundred meters away from a fertile soil area containing the highest organic carbon content of the national park (Beugler-Bell and Buch, 1997). As wind erosion was identified in these nearby fertile soils, aeolian transport potentially led to higher organic matter concentration at the edge of the pan compared to farther towards the center of the pan. Overall, this suggests that the Etosha sample's ice nucleation ability is almost entirely caused by organic matter, potentially cellulose or proteins which were mixed with or adsorbed onto the mineral dust on the ground, explaining the almost complete suppression of ice nucleation of the heated samples.

In contrast to the Etosha sample, the Tenerife2014_1 sample consists of a number of minerals ice nucleation active at the studied temperatures, e.g., orthoclase, plagioclase, and quartz (Table 1). The sample shows the largest mass loss in the TGA analysis. The rather steep step in the TGA 
(a)

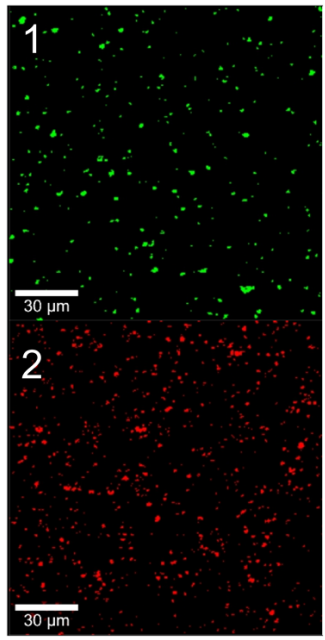

(c)

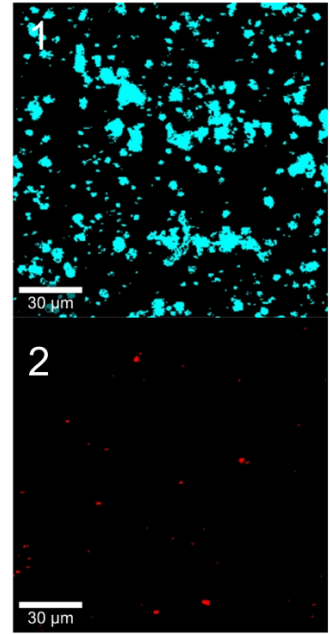

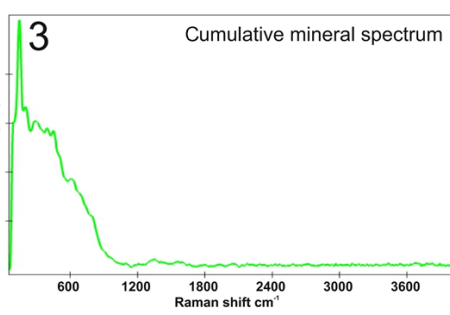
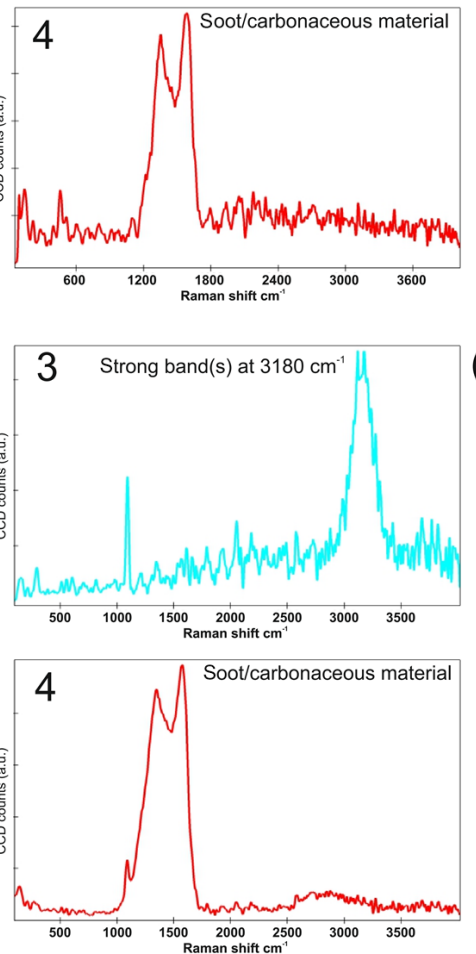

(b)
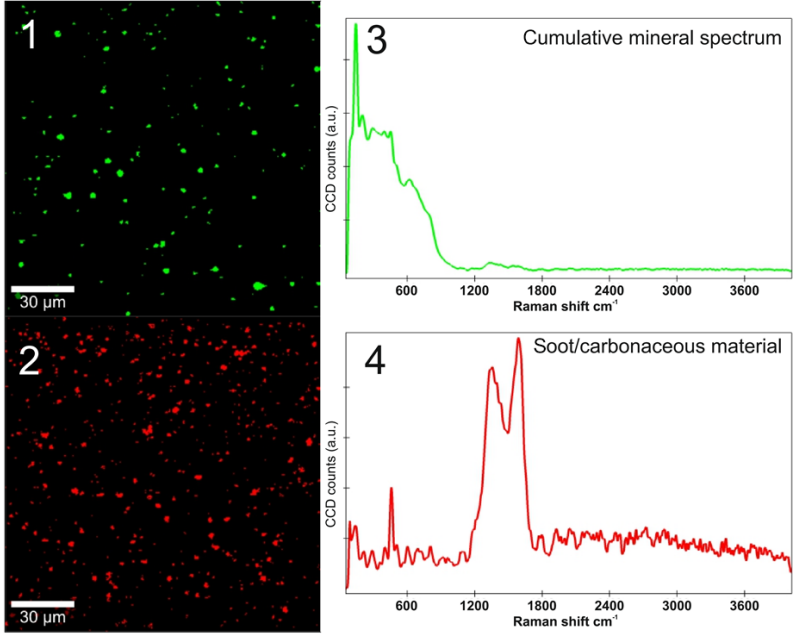

(d)

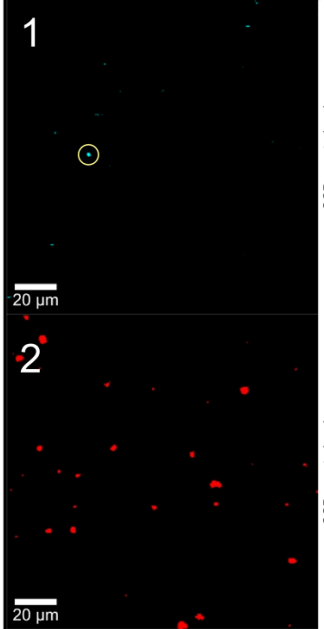

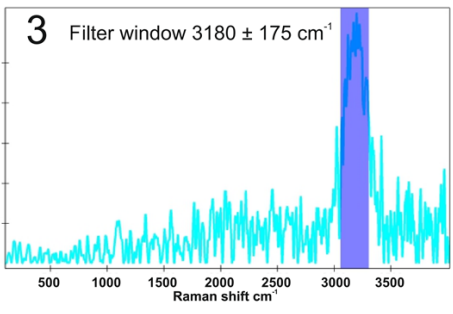

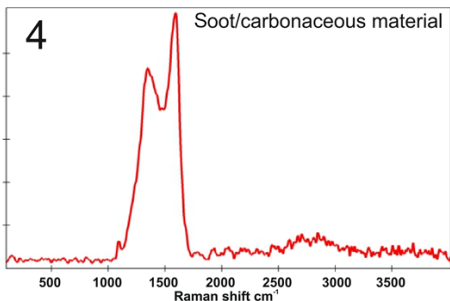

Figure 6. Raman mapping results for the Australia (a, b) and the Etosha sample (c, d). In each panel, (1) and (2) show the location of particles from clusters with spectra similar to those shown in (3) and (4). In (d1) the particle is encircled for which the filter (d3) found a spectrum.

loss curve at about $120^{\circ} \mathrm{C}$ suggests a certain species to be released at this temperature, probably containing aliphatic compounds as suggested by the ATR-IR measurements. The complexity of the airborne Saharan samples is indicated by García et al. (2017), who studied organic material in the Saharan Air Layer. They collected $42 \mathrm{PM}_{2.5}$ and $\mathrm{PM}_{10}$ filters at the Izaña observatory in parallel to the Tenerife2013 sample collection and the CALIMA 2013 campaign in August 2013. Organic matter accounted for about $1.5 \mathrm{wt} \%$ of the aerosol composition in the Saharan Air Layer and was determined to mainly consist of saccharides, related to organic material in soils, biogenic secondary organic aerosol particles resulting from isoprene and $\alpha$-pinene oxidation, and organic compounds from natural and anthropogenic sources such as vegetation and engine emissions. During daytime, the boundary layer reaches the altitude of the Izaña observatory and organic matter can originate from local sources. During nighttime the observatory is located in the free troposphere and aerosol sources are distant. Anthropogenic and natural emis- sions can originate from the North African coast or be advected from Europe (Rodríguez et al., 2011; García et al., 2017). As the dust collection took place over several days and nights, an influence of organic matter from local sources cannot be excluded.

Another explanation for the reduction in mass at temperatures below $300{ }^{\circ} \mathrm{C}$ is the release of free water molecules from the crystal lattice as indicated also in the ATR-IR spectra between 3600 and $3100 \mathrm{~cm}^{-1}$. In some cases, this affects the crystal lattice: Smectite, a swelling mineral, collapses under decreasing water vapor pressure as experienced during the heating. This decreases the interlayer spacing (for an overview of the effect of layer charge on smectite swelling see Laird, 2006). It is unknown if the change in crystal lattice has an effect on the ice nucleation ability of the otherwise only weakly ice nucleation active smectite (Pinti et al., 2012; Kaufmann et al., 2016). An effect cannot be excluded as the lattice match with ice is believed to be one of the factors promoting ice nucleation (Pruppacher and Klett, 1997). In the 


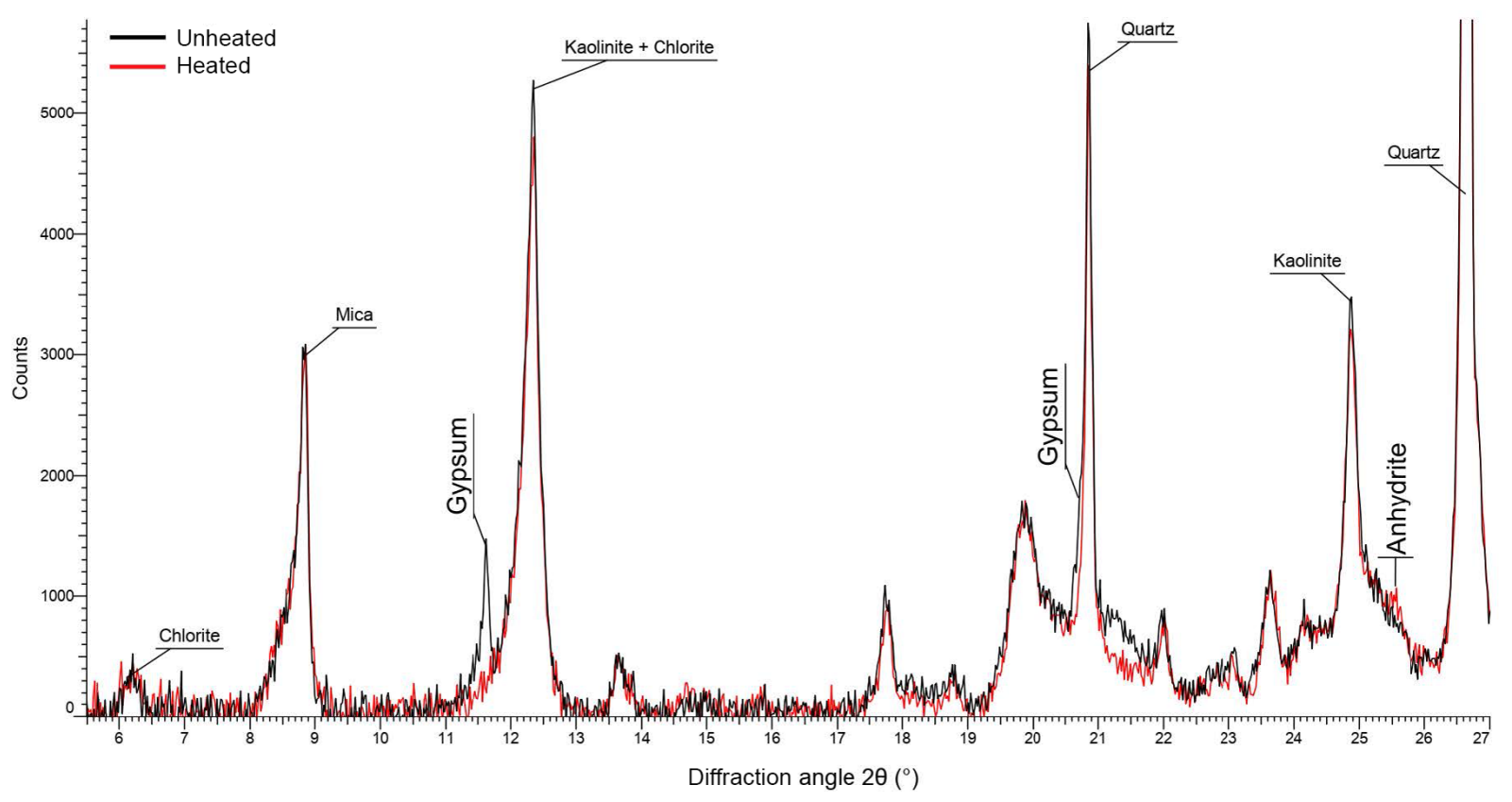

Figure 7. XRD diffractogram of unheated and heated Tenerife2014_1 sample. Vertical text indicates changes in peak height which were used to identify the decrease in gypsum and increase in anhydrite with heating. Horizontal text indicates peaks associated with other minerals in the sample.

studied samples, smectite was present in the Tenerife2014_1 sample ( $23 \mathrm{wt} \%)$, and traces were found in the Etosha sample (1 wt \%). Thus, the collapse of the smectite lattice should only influence the Tenerife2014_1 sample. In case it has an influence, this would be related to an increase in ice nucleation ability.

XRD analysis of the unheated and heated Tenerife2014_1 sample show the conversion of gypsum to anhydrite (Fig. 7). Gypsum has a low ice nucleation ability, similar to the clay minerals kaolinite and illite (Zimmermann et al., 2008). Grawe et al. (2018) found anhydrite to have a higher ice nucleation activity than quartz in the immersion mode at temperatures below $243 \mathrm{~K}$ when dry generated but a much lower $n_{\mathrm{s}}$ when particles were generated from an aqueous solution. Anhydrite transforms back to gypsum when exposed to a relative humidity higher than $97 \%$ at room temperature (Bracconi et al., 2010). However, this process occurs on the order of hours to days, in line with the observed differences in $n_{\mathrm{s}}$ between wet and dry generated particles in Grawe et al. (2018). Potentially, the transformation to anhydrite during heating explains the higher $n_{\mathrm{s}}$ of the heated Tenerife2014_1 sample compared to the unheated one at subsaturated conditions. In this case, a partial conversion of anhydrite back to gypsum during $\mathrm{RH}$ conditions above water saturation might explain the unchanged $n_{\mathrm{s}}$ of the unheated and heated Tenerife2014_1 sample above water saturation. It should be kept in mind that the bulk mineralogy as determined by XRD is not necessarily representative of the particle surface where ice nucleation takes place. As needle formation has been ob- served in the transformation of gypsum to anhydrite (Azimi and Papangelakis, 2011; Grawe et al., 2016), we use the occurrence of needles in our sample as an indication that the gypsum-anhydrite transformation took place on the surface of particles and thus might be responsible for the change in ice nucleation behavior of the sample. In SEM images of the unheated Tenerife2014_1 sample (Fig. 8a), hardly any needles are visible. A small number of needles is observed at the center of the image of the heated sample (Fig. 8b), while no needles are found in other SEM images of the heated sample (see the Supplement). The apparently limited needle formation and the fact that only about $1 \mathrm{wt} \%$ gypsum is contained in the sample suggests that gypsum transformation under heat treatment should only have a small effect on the ice nucleation behavior of the Tenerife2014_1 sample. However, given that, at maximum, only about $10 \%$ of the particles act as INPs in case of the Tenerife2014_1 sample, the gypsumanhydrite transformation might be non-negligible. Additionally, we suggest that the increase in the $n_{\mathrm{S}}$ found under subsaturated $\mathrm{RH}_{\mathrm{w}}$ conditions for the Tenerife2014_1 sample is caused by the volatilization of aliphatic compounds containing matter, as indicated by the ATR-IR and TGA measurements, which inhibited the active sites of the mineral dust itself.

\section{Conclusions}

In this study we showed that the fractions of quartz and the sum of quartz and feldspars in desert dust samples correlate 


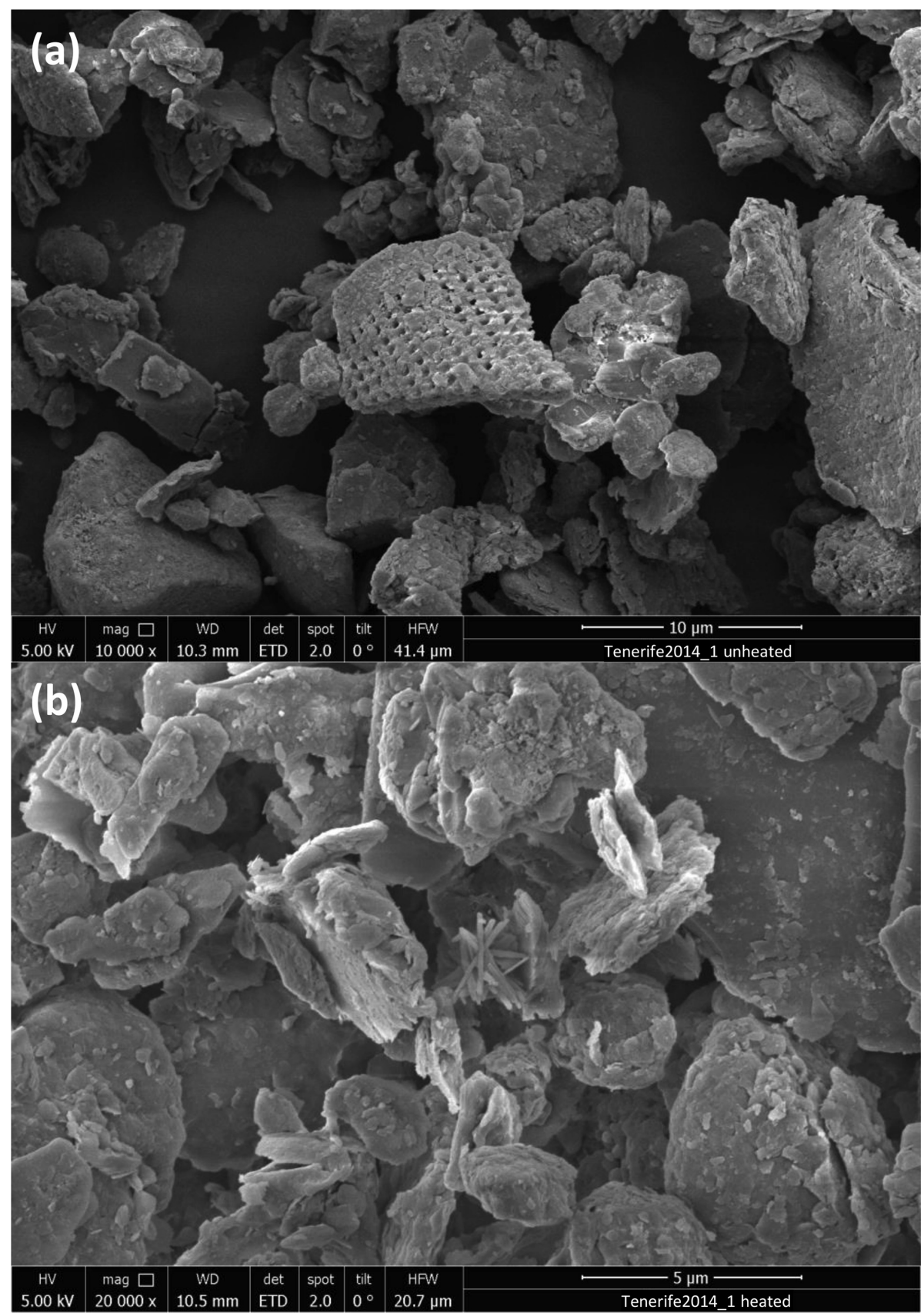

Figure 8. Scanning electron microscopy images of the (a) unheated and (b) heated Tenerife2014_1 sample. Note the different scales in the two images.

better than all other mineral fractions with the ice nucleation active surface site density of the dust in deposition and the condensation mode at temperatures between 238 and $242 \mathrm{~K}$. This is in line with the observations for the immersion mode presented in Part 1 (Boose et al., 2016c) of this study. The high abundance of quartz in soils worldwide, its resistance to chemical weathering processes, and its presence in particles of all sizes make it a potentially widely spread atmospheric INP type. According to a recent study by Kumar et al. (2018b), the variation in quartz ice nucleation ability found in laboratory studies (Atkinson et al., 2013; Zolles et al., 2015; Kaufmann et al., 2016) and the superior ice nucleation ability of the quartz-rich samples from Australia and Morocco in this study and its partner paper may be explained by the preprocessing of the samples. Milling of quartz samples, as done in our study, increases the ice nucleation ability of quartz by creating $\mathrm{Si}-\mathrm{O}$. and $\mathrm{Si}$. radical sites, which can then react with water vapor (Kumar et al., 2018b). However, milling 
may not be the only reason for formation of the silanol $(\mathrm{Si}-\mathrm{OH})$ groups on the surface of quartz, because exposure to water molecules in ambient humidity could also result in passively converting surface siloxane groups $(\mathrm{Si}-\mathrm{O}-\mathrm{Si})$ to silanol groups (Boehm, 1966; Wang et al., 2018). As such quartz samples may still exhibit high ice nucleation activity in the absence of milling due to the chemical history of the particles. Thus, how much quartz contributes to the ice nucleation ability of (unmilled) atmospheric dust remains an open question. Apart from mineralogy, the ice nucleation activity of desert dust is found to be influenced by organic material mixed with the dust. In a carbonaceous sample from the Etosha salt pan, where less than $1 \mathrm{wt} \%$ quartz and no feldspar were present, the ice-active surface site density is found to be almost entirely due to organic matter, likely cellulose or proteins, which are mixed with the dust. In contrast, the deposition-mode ice nucleation activity of an airborne Saharan dust sample was found to increase after heating. Three potential explanations are found, two of them related to changes in the mineralogy; while it cannot be excluded that the increase in the $n_{\mathrm{s}}$ was caused by a change in lattice spacing due to interlayer water release, it seems more likely that gypsum transforming into anhydrite made the sample more ice nucleation active. The Tenerife2014_1 sample is the only gypsum-containing sample that was investigated after heating, thus it remains an open question if and how much anhydrite contributed to the increase in $n_{\mathrm{s}}$. Another reason for the increase could be that the ice nucleation active sites of the unheated sample were blocked by volatile organic material. The volatilization of the aliphatic compounds during the heating recovered these active sites. This is further supported by the observation that no difference was found for the same sample in the condensationfreezing mode, indicating that the water condensing on the surface may also recover the active sites. As this change in ice-active surface site density was not observed for a second airborne Saharan dust sample, it suggests that different aging processes or the mixing of Saharan dust with organic material during atmospheric transport can influence the dust's ice nucleation ability in both directions.

Data availability. Ice nucleation data from this study are available from Boose et al. (2019). Additional SEM images can be found in the Supplement. Additional data are available upon request.

Supplement. The supplement related to this article is available online at: https://doi.org/10.5194/acp-19-1059-2019-supplement.

Author contributions. YB collected the Tenerife and Israel samples, conceived and lead the measurement campaign, performed the ice nucleation measurements and analysis, performed and analyzed the XRD measurements, analyzed the TGA measurements, and wrote the paper. PB performed and analyzed the SEM, ATR-IR, and Raman measurements, and contributed to the paper. JO contributed to the Raman measurements. HG supervised the ATR-IR and Raman measurements and analysis and contributed to the paper. MP performed and analyzed the XRD measurements. ZAK performed the TGA measurements. BS, ZAK, and UL supervised the project and contributed to the paper. All authors contributed to the interpretation of data.

Competing interests. The authors declare no competing interests.

Acknowledgements. We thank the two anonymous reviewers for their helpful comments. The various dust samples in this paper have been collected by a number of people who the authors are very thankful to Maria Kanakidou and her team (Peloponnese, Crete); Felix Lüönd (Atacama); Paolo D'Odorico and Christopher Hoyle (Etosha); Lukas Kaufmann, Konrad Kandler, and Lother Schütz (Taklamakan); André Welti (Australia, Mojave); Monika Kohn (Dubai); Joel Corbin (Morocco); Sergio Rodríguez (Tenerife); and Hamza Mohamed Hamza (Egypt). The authors would like to thank Joanna Wong for her assistance with the TGA measurements and the Laboratory of Composite Materials and Adaptive Structures at ETH Zurich for the use of their thermal analysis equipment. We thank Hannes Wydler for his technical support with the PINC. Philipp Baloh would like to thank Karin Wieland and Rita Wiesinger for helpful discussions concerning the interpretation of the Raman spectra. Hinrich Grothe and Philipp Baloh would like to thank the Analytical Instrumentation Center and the X-Ray Center at TU Wien for the use of the Raman and XRD equipment and the University Service Centre for Transmission Electron Microscopy at TU Wien for recording the SEM images in this work. Yvonne Boose and Zamin A. Kanji gratefully acknowledge support by the Swiss National Science Foundation (grant 200020 150169/1). The research leading to these results has received funding from the European Union's Seventh Framework Programme (FP7/2007-797 2013) under grant agreement no. 603445 (BACCHUS). Hinrich Grothe and Philipp Baloh gratefully acknowledge support by the FFG (Austrian Research Promotion Agency) for funding under project no. 850689.

Edited by: Eliza Harris

Reviewed by: two anonymous referees

\section{References}

Alexander, J. M.: Optical properties of mineral dust aerosol including analysis of particle size, composition, and shape effects, and the impact of physical and chemical processing, $\mathrm{PhD}$ thesis, University of Iowa, 2015.

Archuleta, C. M., DeMott, P. J., and Kreidenweis, S. M.: Ice nucleation by surrogates for atmospheric mineral dust and mineral dust/sulfate particles at cirrus temperatures, Atmos. Chem. Phys., 5, 2617-2634, https://doi.org/10.5194/acp-5-2617-2005, 2005.

Atkinson, J., Murray, B. J., Woodhouse, M. T., Whale, T. F., Baustian, K. J., Carslaw, K. S., Dobbie, S., O'Sullivan, D., and Malkin, T. L.: The importance of feldspar for ice nucleation 
by mineral dust in mixed-phase clouds, Nature, 498, 355-358, https://doi.org/10.1038/nature12278, 2013.

Augustin-Bauditz, S., Wex, H., Kanter, S., Ebert, M., Niedermeier, D., Stolz, F., Prager, A., and Stratmann, F.: The immersion mode ice nucleation behavior of mineral dusts: A comparison of different pure and surface modified dusts, Geophys. Res. Lett., 41, 1-8, https://doi.org/10.1002/2014GL061317, 2014.

Augustin-Bauditz, S., Wex, H., Denjean, C., Hartmann, S., Schneider, J., Schmidt, S., Ebert, M., and Stratmann, F.: Laboratorygenerated mixtures of mineral dust particles with biological substances: characterization of the particle mixing state and immersion freezing behavior, Atmos. Chem. Phys., 16, 5531-5543, https://doi.org/10.5194/acp-16-5531-2016, 2016.

Azimi, G. and Papangelakis, V. G.: Mechanism and kinetics of gypsum-anhydrite transformation in aqueous electrolyte solutions, Hydrometallurgy, 108, 122-129, https://doi.org/10.1016/j.hydromet.2011.03.007, 2011.

Bergmann, J., Friedel, P., and Kleeberg, R.: BGMN - a new fundamental parameters based Rietveld program for laboratory X-ray sources, it's use in quantitative analysis and structure investigations, Commission of Powder Diffraction, International Union of Crystallography, CPD Newslett., 20, 5-8, 1998.

Berner, R. A. and Holdren, G. R.: Mechanism of feldspar weathering: Some observational evidence, Geology, 5, 369-372, https://doi.org/10.1130/00917613(1977)5<369:MOFWSO>2.0.CO;2, 1977.

Bertram, A. K., Martin, S. T., Hanna, S. J., Smith, M. L., Bodsworth, A., Chen, Q., Kuwata, M., Liu, A., You, Y., and Zorn, S. R.: Predicting the relative humidities of liquid-liquid phase separation, efflorescence, and deliquescence of mixed particles of ammonium sulfate, organic material, and water using the organic-to-sulfate mass ratio of the particle and the oxygen-tocarbon elemental ratio of the organic component, Atmos. Chem. Phys., 11, 10995-11006, https://doi.org/10.5194/acp-11-109952011, 2011.

Beugler-Bell, H. and Buch, M. W.: Soils and soil erosion in the Etosha National Park, northern Namibia, Madoqua, 20, 91-104, 1997.

Bish, D. L. and Plötze, M.: X-ray powder diffraction with emphasis on qualitative and quantitative analysis in industrial mineralogy, in: Industrial Mineralogy, European Mineralogical Union Notes in Mineralogy, edited by: Christidis, G., vol. 9, chap. 3, 35-76, https://doi.org/10.1180/emu-notes.2010.emu9-3, 2011.

Boehm, H.-P.: Functional Groups on the Surfaces of Solids, Angew. Chem. Int. Edit., 5, 533-544, https://doi.org/10.1002/anie.196605331, 1966.

Boose, Y., Kanji, Z. A., Kohn, M., Sierau, B., Zipori, A., Crawford, I., Lloyd, G., Bukowiecki, N., Herrmann, E., Kupiszewski, P., Steinbacher, M., and Lohmann, U.: Ice Nucleating Particle Measurements at $241 \mathrm{~K}$ during Winter Months at 3580 MSL in the Swiss Alps, J. Atmos. Sci., 73, 2203-2228, https://doi.org/10.1175/JAS-D-15-0236.1, 2016a.

Boose, Y., Sierau, B., García, M. I., Rodríguez, S., Alastuey, A., Linke, C., Schnaiter, M., Kupiszewski, P., Kanji, Z. A., and Lohmann, U.: Ice nucleating particles in the Saharan Air Layer, Atmos. Chem. Phys., 16, 9067-9087, https://doi.org/10.5194/acp-16-9067-2016, 2016b.

Boose, Y., Welti, A., Atkinson, J., Ramelli, F., Danielczok, A., Bingemer, H. G., Plötze, M., Sierau, B., Kanji, Z. A., and
Lohmann, U.: Heterogeneous ice nucleation on dust particles sourced from nine deserts worldwide - Part 1: Immersion freezing, Atmos. Chem. Phys., 16, 15075-15095, https://doi.org/10.5194/acp-16-15075-2016, 2016c.

Boose, Y., Baloh, P., Plötze, M., Ofner, J., Grothe, H., Sierau, B., Lohmann, U., and Kanji, Z. A.: Heterogeneous ice nucleation on dust particles sourced from 9 deserts worldwide - Part 2: Deposition nucleation and condensation freezing, https://doi.org/10.3929/ethz-b-5 000314622, 2019.

Boucher, O., Randall, D., Artaxo, P., Bretherton, C., Feingold, G., Forster, P., Kerminen, V.-M., Kondo, Y., Liao, H., Lohmann, U., Rasch, P., Satheesh, S., Sherwood, S., Stevens, B., and Zhang, X.: Clouds and Aerosols. In: Climate Change 2013: The Physical Science Basis, Contribution of Working Group I to the Fifth Assessment Report of the Intergovernmental Panel on Climate Change, edited by: Stocker, T. F., Qin, D., Plattner, G.-K., Tignor, M., Allen, S. K., Boschung, J., Nauels, A., Xia, Y., Bex, V., and Midgley, P. M., Cambridge University Press, Cambridge, UK, New York, NY, USA, 2013.

Bracconi, P., Cyrille, A., and Mutin, J.-C.: Interaction of CaSO4 with water vapour at high relative humidity, Open archive (HAL), available at: https://hal.archives-ouvertes.fr/hal-00454539 (last access: 23 January 2019), 2010.

Chou, C., Stetzer, O., Weingartner, E., Jurányi, Z., Kanji, Z. A., and Lohmann, U.: Ice nuclei properties within a Saharan dust event at the Jungfraujoch in the Swiss Alps, Atmos. Chem. Phys., 11, 4725-4738, https://doi.org/10.5194/acp-11-4725-2011, 2011.

Coluzza, I., Creamean, J., Rossi, J. M., Wex, H., Alpert, A. P., Bianco, V., Boose, Y., Dellago, C., Felgitsch, L., FröhlichNowoisky, J., Herrmann, H., Jungblut, S., Kanji, A. Z., Menzl, G., Moffett, B., Moritz, C., Mutzel, A., Pöschl, U., Schauperl, M., Scheel, J., Stopelli, E., Stratmann, F., Grothe, H., and Schmale, G. D.: Perspectives on the Future of Ice Nucleation Research: Research Needs and Unanswered Questions Identified from Two International Workshops, Atmosphere, 8, 138, https://doi.org/10.3390/atmos8080138, 2017.

Conen, F., Morris, C. E., Leifeld, J., Yakutin, M. V., and Alewell, C.: Biological residues define the ice nucleation properties of soil dust, Atmos. Chem. Phys., 11, 9643-9648, https://doi.org/10.5194/acp-11-9643-2011, 2011

Connolly, P. J., Möhler, O., Field, P. R., Saathoff, H., Burgess, R., Choularton, T., and Gallagher, M.: Studies of heterogeneous freezing by three different desert dust samples, Atmos. Chem. Phys., 9, 2805-2824, https://doi.org/10.5194/acp-9-2805-2009, 2009.

Cozic, J., Mertes, S., Verheggen, B., Cziczo, D. J., Gallavardin, S. J., Walter, S., Baltensperger, U., and Weingartner, E.: Black carbon enrichment in atmospheric ice particle residuals observed in lower tropospheric mixed phase clouds, J. Geophys. Res.Atmos., 113, D15209, https://doi.org/10.1029/2007JD009266, 2008.

Creamean, J. M., Suski, K. J., Rosenfeld, D., Cazorla, A., DeMott, P. J., Sullivan, R. C., White, A. B., Ralph, F. M., Minnis, P., Comstock, J. M., Tomlinson, J. M., and Prather, K. A.: Dust and Biological Aerosols from the Sahara and Asia Influence Precipitation in the Western U.S., Science, 339, 1572-1578, https://doi.org/10.1126/science.1227279, 2013.

Cziczo, D. J., Froyd, K. D., Hoose, C., Jensen, E. J., Diao, M., Zondlo, M. A., Smith, J. B., Twohy, C. H., and Mur- 
phy, D. M.: Clarifying the Dominant Sources and Mechanisms of Cirrus Cloud Formation, Science, 340, 1320-1324, https://doi.org/10.1126/science.1234145, 2013.

Dall'Osto, M., Harrison, R. M., Highwood, E. J., O’Dowd, C., Ceburnis, D., Querol, X., and Achterberg, E. P.: Variation of the mixing state of Saharan dust particles with atmospheric transport, Atmos. Environ., 44, 3135-3146, https://doi.org/10.1016/j.atmosenv.2010.05.030, 2010.

DeMott, P. J., Sassen, K., Poellot, M., Baumgardner, D., Rogers, D., Brooks, S., Prenni, A., and Kreidenweis, S.: African dust aerosols as atmospheric ice nuclei, Geophys. Res. Lett., 30, 1732, https://doi.org/10.1029/2003GL017410, 2003.

Engelstaedter, S., Tegen, I., and Washington, R.: North African dust emissions and transport, Earth Sci. Rev., 79, 73-100, https://doi.org/10.1016/j.earscirev.2006.06.004, 2006.

Fletcher, N. H.: Active sites and ice crystal nucleation, J. Atmos. Sci., 26, 1266-1271, 1969.

Földvári, M.: Handbook of thermogravimetric system of minerals and its use in geological practice, Occasional Papers of the Geological Institute of Hungary, 2011.

García, M. I., van Drooge, B. L., Rodríguez, S., and Alastuey, A.: Speciation of organic aerosols in the Saharan Air Layer and in the free troposphere westerlies, Atmos. Chem. Phys., 17, 89398958, https://doi.org/10.5194/acp-17-8939-2017, 2017.

Garimella, S., Rothenberg, D. A., Wolf, M. J., David, R. O., Kanji, Z. A., Wang, C., Rösch, M., and Cziczo, D. J.: Uncertainty in counting ice nucleating particles with continuous flow diffusion chambers, Atmos. Chem. Phys., 17, 10855-10864, https://doi.org/10.5194/acp-17-10855-2017, 2017.

Goldich, S. S.: A Study in Rock-Weathering, J. Geol., 46, 17-58, https://doi.org/10.1086/624619, 1938.

Grawe, S., Augustin-Bauditz, S., Hartmann, S., Hellner, L., Pettersson, J. B. C., Prager, A., Stratmann, F., and Wex, H.: The immersion freezing behavior of ash particles from wood and brown coal burning, Atmos. Chem. Phys., 16, 13911-13928, https://doi.org/10.5194/acp-16-13911-2016, 2016.

Grawe, S., Augustin-Bauditz, S., Clemen, H.-C., Ebert, M., Eriksen Hammer, S., Lubitz, J., Reicher, N., Rudich, Y., Schneider, J., Staacke, R., Stratmann, F., Welti, A., and Wex, H.: Coal fly ash: linking immersion freezing behavior and physicochemical particle properties, Atmos. Chem. Phys., 18, 13903-13923, https://doi.org/10.5194/acp-18-13903-2018, 2018.

Hande, L. B., Engler, C., Hoose, C., and Tegen, I.: Seasonal variability of Saharan desert dust and ice nucleating particles over Europe, Atmos. Chem. Phys., 15, 4389-4397, https://doi.org/10.5194/acp-15-4389-2015, 2015.

Hara, K. and Zhang, D.: Bacterial abundance and viability in long-range transported dust, Atmos. Environ., 47, 20-25, https://doi.org/10.1016/j.atmosenv.2011.11.050, 2012.

Harrison, A. D., Whale, T. F., Carpenter, M. A., Holden, M. A., Neve, L., O'Sullivan, D., Vergara Temprado, J., and Murray, B. J.: Not all feldspars are equal: a survey of ice nucleating properties across the feldspar group of minerals, Atmos. Chem. Phys., 16, 10927-10940, https://doi.org/10.5194/acp-16-109272016, 2016.

Hinds, W.: Aerosol Technology Properties, Behavior, and Measurement of Airborne Particles, 2nd edn., John Wiley \& Sons, Inc., 1999.
Hiranuma, N., Augustin-Bauditz, S., Bingemer, H., Budke, C., Curtius, J., Danielczok, A., Diehl, K., Dreischmeier, K., Ebert, M., Frank, F., Hoffmann, N., Kandler, K., Kiselev, A., Koop, T., Leisner, T., Möhler, O., Nillius, B., Peckhaus, A., Rose, D., Weinbruch, S., Wex, H., Boose, Y., DeMott, P. J., Hader, J. D., Hill, T. C. J., Kanji, Z. A., Kulkarni, G., Levin, E. J. T., McCluskey, C. S., Murakami, M., Murray, B. J., Niedermeier, D., Petters, M. D., O'Sullivan, D., Saito, A., Schill, G. P., Tajiri, T., Tolbert, M. A., Welti, A., Whale, T. F., Wright, T. P., and Yamashita, K.: A comprehensive laboratory study on the immersion freezing behavior of illite NX particles: a comparison of 17 ice nucleation measurement techniques, Atmos. Chem. Phys., 15, 2489-2518, https://doi.org/10.5194/acp-15-2489-2015, 2015a.

Hiranuma, N., Möhler, O., Yamashita, K., Tajiri, T., Saito, A., Kiselev, A., Hoffmann, N., Hoose, C., Jantsch, E., Koop, T., and Murakami, M.: Ice nucleation by cellulose and its potential contribution to ice formation in clouds, Nat. Geosci., 8, 273-277, https://doi.org/10.1038/ngeo2374, 2015b.

Hiranuma, N., Adachi, K., Bell, D., Belosi, F., Beydoun, H., Bhaduri, B., Bingemer, H., Budke, C., Clemen, H.-C., Conen, F., Cory, K., Curtius, J., DeMott, P., Eppers, O., Grawe, S., Hartmann, S., Hoffmann, N., Höhler, K., Jantsch, E., Kiselev, A., Koop, T., Kulkarni, G., Mayer, A., Murakami, M., Murray, B., Nicosia, A., Petters, M., Piazza, M., Polen, M., Reicher, N., Rudich, Y., Saito, A., Santachiara, G., Schiebel, T., Schill, G., Schneider, J., Segev, L., Stopelli, E., Sullivan, R., Suski, K., Szakáll, M., Tajiri, T., Taylor, H., Tobo, Y., Weber, D., Wex, H., Whale, T., Whiteside, C., Yamashita, K., Zelenyuk, A., and Möhler, O.: A comprehensive characterization of ice nucleation by three different types of cellulose particles immersed in water: lessons learned and future research directions, Atmos. Chem. Phys. Discuss., https://doi.org/10.5194/acp-2018-933, in review, 2018.

Kamide, K.: Cellulose and Cellulose Derivatives, Elsevier, 2005.

Kamphus, M., Ettner-Mahl, M., Klimach, T., Drewnick, F., Keller, L., Cziczo, D. J., Mertes, S., Borrmann, S., and Curtius, J.: Chemical composition of ambient aerosol, ice residues and cloud droplet residues in mixed-phase clouds: single particle analysis during the Cloud and Aerosol Characterization Experiment (CLACE 6), Atmos. Chem. Phys., 10, 8077-8095, https://doi.org/10.5194/acp-10-8077-2010, 2010.

Kandler, K., Benker, N., Bundke, U., Cuevas, E., Ebert, M., Knippertz, P., Rodríguez, S., Schütz, L., and Weinbruch, S.: Chemical composition and complex refractive index of Saharan Mineral Dust at Izaña, Tenerife (Spain) derived by electron microscopy, Atmos. Environ., 41, 8058-8074, https://doi.org/10.1016/j.atmosenv.2007.06.047, 2007.

Kandler, K., Schütz, L., Deutscher, C., Ebert, M., Hofmann, H., Jäckl, S., Jaenicke, R., Knippertz, P., Lieke, K., Massling, A., Petzold, A., Schladitz, A., Weinzierl, B., Wiedensohler, A., Zorn, S., and Weinbruch, S.: Size distribution, mass concentration, chemical and mineralogical composition and derived optical parameters of the boundary layer aerosol at Tinfou, Morocco, during SAMUM 2006, Tellus B, 61, 32-50, https://doi.org/10.1111/j.1600-0889.2008.00385.x, 2009.

Kanji, Z. A., Welti, A., Chou, C., Stetzer, O., and Lohmann, U.: Laboratory studies of immersion and deposition mode ice nucleation of ozone aged mineral dust particles, Atmos. 
Chem. Phys., 13, 9097-9118, https://doi.org/10.5194/acp-139097-2013, 2013.

Kanji, Z. A., Ladino, L. A., Wex, H., Boose, Y., BurkertKohn, M., Cziczo, D. J., and Krämer, M.: Overview of Ice Nucleating Particles, Meteorol. Monogr., 58, 133, https://doi.org/10.1175/AMSMONOGRAPHS-D-16-0006.1, 2017.

Kanji, Z. A., Sullivan, R. C., Niemand, M., DeMott, P. J., Prenni, A. J., Chou, C., Saathoff, H., and Möhler, O.: Heterogeneous Ice Nucleation Properties of Natural Desert Dust Particles Coated with a Surrogate of Secondary Organic Aerosol, Atmos. Chem. Phys. Discuss., https://doi.org/10.5194/acp-2018-905, in review, 2018.

Kaufmann, L., Marcolli, C., Hofer, J., Pinti, V., Hoyle, C. R., and Peter, T.: Ice nucleation efficiency of natural dust samples in the immersion mode, Atmos. Chem. Phys., 16, 11177-11206, https://doi.org/10.5194/acp-16-11177-2016, 2016.

Kiselev, A., Bachmann, F., Pedevilla, P., Cox, S. J., Michaelides, A., Gerthsen, D., and Leisner, T.: Active sites in heterogeneous ice nucleation - the example of K-rich feldspars, Science, 355, 367-371, https://doi.org/10.1126/science.aai8034, 2017.

Koehler, K. A., Kreidenweis, S. M., DeMott, P. J., Petters, M. D., Prenni, A. J., and Möhler, O.: Laboratory investigations of the impact of mineral dust aerosol on cold cloud formation, Atmos. Chem. Phys., 10, 11955-11968, https://doi.org/10.5194/acp-1011955-2010, 2010.

Koop, T., Luo, B., Tsias, A., and Peter, T.: Water activity as the determinant for homogeneous ice nucleation in aqueous solutions, Nature, 406, 611-614, https://doi.org/10.1038/35020537, 2000.

Kristensen, E.: Characterization of Biogenic Organic Matter by Stepwise Thermogravimetry (STG), Biogeochemistry, 9, 135159, 1990.

Kumai, M.: Identification of Nuclei and Concentrations of Chemical Species in Snow Crystals Sampled at the South Pole, J. Atmos. Sci., 33, 833-841, https://doi.org/10.1175/15200469(1976)033<0833:IONACO>2.0.CO;2, 1976.

Kumar, A., Marcolli, C., Luo, B., and Peter, T.: Ice nucleation activity of silicates and aluminosilicates in pure water and aqueous solutions - Part 1: The K-feldspar microcline, Atmos. Chem. Phys., 18, 7057-7079, https://doi.org/10.5194/acp18-7057-2018, 2018a.

Kumar, A., Marcolli, C., and Peter, T.: Ice nucleation activity of silicates and aluminosilicates in pure water and aqueous solutions. Part 2 - Quartz and amorphous silica, Atmos. Chem. Phys. Discuss., https://doi.org/10.5194/acp-2018-1020, in review, 2018 b.

Kupiszewski, P., Weingartner, E., Vochezer, P., Schnaiter, M., Bigi, A., Gysel, M., Rosati, B., Toprak, E., Mertes, S., and Baltensperger, U.: The Ice Selective Inlet: a novel technique for exclusive extraction of pristine ice crystals in mixed-phase clouds, Atmos. Meas. Tech., 8, 3087-3106, https://doi.org/10.5194/amt8-3087-2015, 2015.

Lafuente, B., Downs, R., Yang, H., Stone, N., Armbruster, T., and Danisi, R.: Highlights in mineralogical crystallography, W. De Gruyter, Berlin, 1-30, 2015.

Laird, D. A.: Influence of layer charge on swelling of smectites, Appl. Clay Sci., 34, 74-87, https://doi.org/10.1016/j.clay.2006.01.009, 2006.
Langham, E. J. and Mason, B. J.: The Heterogeneous and Homogeneous Nucleation of Supercooled Water, Proc. Roy. Soc. A, 247, 493-504, https://doi.org/10.1098/rspa.1958.0207, 1958.

Lipska, A. E. and Parker, W. J.: Kinetics of the pyrolysis of cellulose in the temperature range $250-300^{\circ} \mathrm{C}$, J. Appl. Polym. Sci., 10, 1439-1453, https://doi.org/10.1002/app.1966.070101005, 1966.

Maki, L. R., Galyan, E. L., Chang-Chien, M.-M., and Caldwell, D. R.: Ice Nucleation Induced by Pseudomonas syringae, Appl. Microbiol., 28, 456-459, 1974.

Marcolli, C.: Deposition nucleation viewed as homogeneous or immersion freezing in pores and cavities, Atmos. Chem. Phys., 14, 2071-2104, https://doi.org/10.5194/acp-14-2071-2014, 2014.

Marcolli, C.: Pre-activation of aerosol particles by ice preserved in pores, Atmos. Chem. Phys., 17, 1595-1622, https://doi.org/10.5194/acp-17-1595-2017, 2017.

Marcolli, C., Gedamke, S., Peter, T., and Zobrist, B.: Efficiency of immersion mode ice nucleation on surrogates of mineral dust, Atmos. Chem. Phys., 7, 5081-5091, https://doi.org/10.5194/acp7-5081-2007, 2007.

Miyazawa, M., Pavan, M., Oliveira, E. d., Ionashiro, M., and Silva, A.: Gravimetric determination of soil organic matter, Braz. Arch. Biol. Technol., 43, 475-478, https://doi.org/10.1590/S151689132000000500005, 2000.

Möhler, O., Benz, S., Saathoff, H., Schnaiter, M., Wagner, R., Schneider, J., Walter, S., Ebert, V., and Wagner, S.: The effect of organic coating on the heterogeneous ice nucleation efficiency of mineral dust aerosols, Environ. Res. Lett., 3, 025007, https://doi.org/10.1088/1748-9326/3/2/025007, 2008.

Ofner, J., Kirschner, J., Eitenberger, E., Friedbacher, G., KasperGiebl, A., Lohninger, H., Eisenmenger-Sittner, C., and Lendl, B.: A novel substrate for multisensor hyperspectral imaging, J. Microsc., 265, 341-348, https://doi.org/10.1111/jmi.12506, 2017.

O’Sullivan, D., Murray, B. J., Ross, J. F., Whale, T. F., Price, H. C., Atkinson, J. D., Umo, N. S., and Webb, M. E.: The relevance of nanoscale biological fragments for ice nucleation in clouds, Sci. Rep., 5, 8082, https://doi.org/10.1038/srep08082, 2015.

O'Sullivan, D., Murray, B. J., Ross, J. F., and Webb, M. E.: The adsorption of fungal ice-nucleating proteins on mineral dusts: a terrestrial reservoir of atmospheric ice-nucleating particles, Atmos. Chem. Phys., 16, 7879-7887, https://doi.org/10.5194/acp16-7879-2016, 2016.

Paramonov, M., David, R. O., Kretzschmar, R., and Kanji, Z. A.: A laboratory investigation of the ice nucleation efficiency of three types of mineral and soil dust, Atmos. Chem. Phys., 18, 1651516536, https://doi.org/10.5194/acp-18-16515-2018, 2018.

Pinti, V., Marcolli, C., Zobrist, B., Hoyle, C. R., and Peter, T.: Ice nucleation efficiency of clay minerals in the immersion mode, Atmos. Chem. Phys., 12, 5859-5878, https://doi.org/10.5194/acp-12-5859-2012, 2012.

Pouleur, S., Richard, C., Martin, J.-G., and Antoun, H.: Ice Nucleation Activity in Fusarium acuminatum and Fusarium avenaceum, Appl. Environ. Microbiol., 58, 2960-2964, 1992.

Pruppacher, H. R. and Klett, J. D.: Microphysics of clouds and precipitation, 2nd edn., Kluwer Academic Publishers New York, Boston, Dordrecht, London, Moscow, 1997.

Rietveld, H. M.: A profile refinement method for nuclear and magnetic structures, J. Appl. Crystallogr., 2, 65-71, https://doi.org/10.1107/S0021889869006558, 1969. 
Rodríguez, S., Alastuey, A., Alonso-Pérez, S., Querol, X., Cuevas, E., Abreu-Afonso, J., Viana, M., Pérez, N., Pandolfi, M., and de la Rosa, J.: Transport of desert dust mixed with North African industrial pollutants in the subtropical Saharan Air Layer, Atmos. Chem. Phys., 11, 6663-6685, https://doi.org/10.5194/acp11-6663-2011, 2011.

Sadezky, A., Muckenhuber, H., Grothe, H., Niessner, R., and Pöschl, U.: Raman microspectroscopy of soot and related carbonaceous materials: Spectral analysis and structural information, Carbon, 43, 1731-1742, https://doi.org/10.1016/j.carbon.2005.02.018, 2005.

Schaefer, V. J.: The Formation of Ice Crystals in the Laboratory and the Atmosphere, Chem. Rev., 44, 291-320, https://doi.org/10.1021/cr60138a004, 1949.

Schnell, R. C.: Ice Nuclei in Seawater, Fog Water and Marine Air off the Coast of Nova Scotia: Summer 1975, J. Atmos. Sci., 34, 1299-1305, https://doi.org/10.1175/15200469(1977)034<1299:INISFW>2.0.CO;2, 1977.

Socrates, G.: Infrared and Raman Characteristic Group Frequencies - Tables and Charts, John Wiley \& Sons, Ltd, 2001.

Stamm, A. J.: Thermal Degradation of Wood and Cellulose, Ind. Eng. Chem., 48, 413-417, https://doi.org/10.1021/ie51398a022, 1956.

Sullivan, R. C., Petters, M. D., DeMott, P. J., Kreidenweis, S. M., Wex, H., Niedermeier, D., Hartmann, S., Clauss, T., Stratmann, F., Reitz, P., Schneider, J., and Sierau, B.: Irreversible loss of ice nucleation active sites in mineral dust particles caused by sulphuric acid condensation, Atmos. Chem. Phys., 10, 1147111487, https://doi.org/10.5194/acp-10-11471-2010, 2010.

Thomas, A. D., Dougill, A. J., Elliott, D. R., and Mairs, H.: Seasonal differences in soil $\mathrm{CO}_{2}$ efflux and carbon storage in Ntwetwe Pan, Makgadikgadi Basin, Botswana, Geoderma, 219-220, 7281, https://doi.org/10.1016/j.geoderma.2013.12.028, 2014.

Troeh, F. R. and Thompson, L. M.: Soils and Soil Fertility, 6th edn. Ames, Blackwell Pub., 2005.

Vali, G.: Sizes of Atmospheric Ice Nuclei, Nature, 212, 384-385, https://doi.org/10.1038/212384a0, 1966.

Vali, G.: Atmospheric ice nucleation - a review, J. Rech. Atmos., 19, 105-115, 1985.

Vali, G., DeMott, P. J., Möhler, O., and Whale, T. F.: Technical Note: A proposal for ice nucleation terminology, Atmos. Chem. Phys., 15, 10263-10270, https://doi.org/10.5194/acp-15-102632015, 2015.

Vergara-Temprado, J., Murray, B. J., Wilson, T. W., O’Sullivan, D., Browse, J., Pringle, K. J., Ardon-Dryer, K., Bertram, A. K., Burrows, S. M., Ceburnis, D., DeMott, P. J., Mason, R. H., O'Dowd, C. D., Rinaldi, M., and Carslaw, K. S.: Contribution of feldspar and marine organic aerosols to global ice nucleating particle concentrations, Atmos. Chem. Phys., 17, 3637-3658, https://doi.org/10.5194/acp-17-3637-2017, 2017.
Wang, X., Zhang, Q., Li, X., Ye, J., and Li, L.: Structural and Electronic Properties of Different Terminations for Quartz (001) Surfaces as Well as Water Molecule Adsorption on It: A First-Principles Study, Minerals, 8, 58, https://doi.org/10.3390/min8020058, 2018.

Welti, A., Lüönd, F., Stetzer, O., and Lohmann, U.: Influence of particle size on the ice nucleating ability of mineral dusts, Atmos. Chem. Phys., 9, 6705-6715, https://doi.org/10.5194/acp-9-67052009, 2009.

Wex, H., DeMott, P. J., Tobo, Y., Hartmann, S., Rösch, M., Clauss, T., Tomsche, L., Niedermeier, D., and Stratmann, F.: Kaolinite particles as ice nuclei: learning from the use of different kaolinite samples and different coatings, Atmos. Chem. Phys., 14, 55295546, https://doi.org/10.5194/acp-14-5529-2014, 2014.

Whale, T., Holden, M., Kulak, A., Kim, Y., Meldrum, F., Christenson, H., and Murray, B.: The role phase-separation and related topography in the exceptional ice-nucleating ability alkali feldspars, Phys. Chem. Chem. Phys., 19, 31186-31193, https://doi.org/10.1039/c7cp04898j, 2017.

Whale, T. F., Holden, M. A., Wilson, T. W., O'Sullivan, D., and Murray, B. J.: The enhancement and suppression of immersion mode heterogeneous ice-nucleation by solutes, Chem. Sci., 9, 4142-4151, https://doi.org/10.1039/C7SC05421A, 2018.

Xi, Y., Ding, Z., He, H., and Frost, R. L.: Structure of organoclays - an X-ray diffraction and thermogravimetric analysis study , J. Colloid Interface Sci., 277, 116-120, https://doi.org/10.1016/j.jcis.2004.04.053, 2004.

Yakobi-Hancock, J. D., Ladino, L. A., and Abbatt, J. P. D.: Feldspar minerals as efficient deposition ice nuclei, Atmos. Chem. Phys., 13, 11175-11185, https://doi.org/10.5194/acp-13-11175-2013, 2013.

Zimmermann, F., Weinbruch, S., Schütz, L., Hofmann, H., Ebert, M., Kandler, K., and Worringen, A.: Ice nucleation properties of the most abundant mineral dust phases, J. Geophys. Res.-Atmos., 113, 1-11, https://doi.org/10.1029/2008JD010655, 2008.

Zolles, T., Burkart, J., Häusler, T., Pummer, B., Hitzenberger, R., and Grothe, H.: Identification of Ice Nucleation Active Sites on Feldspar Dust Particles, J. Phys. Chem. A, 119, 2692-2700, https://doi.org/10.1021/jp509839x, 2015.

Zuberi, B., Bertram, A. K., Cassa, C. A., Molina, L. T., and Molina, M. J.: Heterogeneous nucleation of ice in $\left(\mathrm{NH}_{4}\right)_{2} \mathrm{SO}_{4}-\mathrm{H}_{2} \mathrm{O}$ particles with mineral dust immersions, Geophys. Res. Lett., 29, 1504, https://doi.org/10.1029/2001GL014289, 2002. 